\title{
SHIFTING TOWARDS A EUROPEAN ROE $v$. WADE: SHOULD JUDICIAL ACTIVISM CREATE AN INTERNATIONAL RIGHT TO ABORTION WITH A., B. AND C. v. IRELAND?
}

\author{
Emma Finney
}

[The] view, in a nutshell, is that every major social ill in this country can find its cure in some Constitutional "principle" and that this Court should "take the lead" in promoting reform when other branches of government fail to act. The Constitution is not a panacea for every blot upon the public welfare, nor should this Court, ordained as a judicial body, be thought of as a general haven for reform movements. ${ }^{1}$

Increasingly, countries are beginning to look to their respective judiciary to be the keeper of morality and the final voice on difficult complex issues. ${ }^{2}$ Whether dissatisfaction with the legislative process or simply a willingness on the part of the judiciary to shape the culture, advocates for socially progressive norms have repeatedly invoked the power of the courts to affect changes in the culture outside of the democratic processes. ${ }^{3}$ These causes are characterized

$\dagger \quad$ University of Pittsburgh School of Law, J.D. expected May 2011, Grove City College, B.A. 2008. I would like to thank Professor de Freitas for alerting me to A., B. and C. v. Ireland. I also want to thank Bill Saunders for his guidance and help in obtaining the difficult to procure case materials and to thank Wes Rist, Andrew Graham, and Amy DiBella for their advice, time, and editing suggestions. Any errors are my own.

1. Reynolds v. Sims, 377 U.S. 533, 624-25 (1964) (Harlan, J., dissenting).

2. Using America as an example, suits against the controversial Patient Protection and Affordable Care Act were filed within minutes of President Obama signing the Health Care Bill into law. Many are hoping that the Supreme Court can end the controversy. See Rosalind S. Helderman, Cuccinelli Forges His Own Path in Suing U.S. Government over Law, WASH. Post, Mar. 24, 2010, at A01; John Schwartz, Health Measure's Opponents Plan Legal Challenges, N.Y. Times, Mar. 23, 2010, at 20; Mike Wereschagin, Line Forms to Challenge Health Care Overhaul Bill, PitT. TriB.-Rev., Mar. 23, 2010, at A1.

3. The European Court of Human Rights is currently considering Ireland's abortion regulations. Statement of Facts, A., B. \& C. v. Ireland, App. No. 25579/05 (Eur. Ct. H.R. filed July 15, 2005), available at http://www.eclj.org/PDF/081118_ECLJ_StatementofFacts7May2008.pdf. The United Kingdom has considered and reconsidered cases about the legality of transporting a close relative to Switzerland for assisted suicide without fear of legal repercussions upon return to England. Pretty v. DPP, [2001] UKHL 61, [2002] 1 All ER 1 (appeal taken from Eng.); R. v. DPP, [2009] UKHL 45 (appeal taken from Eng.). A United States court is considering whether a referendum defining marriage to mean one man and one woman is unconstitutional in Perry v. Schwarzenegger. See Editorial, The Public and Prop. 8, L.A. Times, Jan. 11, 2010, at 18; Max Fisher, Proposition 8 Court Challenge: Too Risky?, The Atlantic Wire (Jan. 11, 2010), http://www.theatlanticwire.com/opinions/view/opinion/Proposition-8-Court-ChallengeToo-Risky-2139. 
by the moral dimension of their scope, and distinguished largely by the relative absence of any positive legal foundation upon which adjudication can be made. Despite this, with escalating frequency courts are being urged to decide divisive issues once for all. Now, with the appearance of $A$., $B$. and $C$. v. Ireland, the European Court of Human Rights is presented with the same jurisprudential problem. People often equate legality with morality. ${ }^{4}$ This practice belies confusion of legal and moral authority; of democratic and legal force.

In the United States, the combatants of the culture wars have made considerable efforts to reshape the moral landscape through the coercive power of the courts. ${ }^{5}$ In Planned Parenthood of Southeastern Pennsylvania $v$. Casey, the U.S. Supreme Court demonstrated its willingness to have the last word on the abortion debate and the majority revealed that they valued a desire to retain a position of power over a chance to reconsider the plight of the unborn, even after the United States Department of Justice repeatedly requested they do so. ${ }^{6}$ As a rule in democracies, legislatures are the branches

4. See George C. Christie, On the Moral Obligation to Obey the Law, 1990 DukE L.J. 1311, 1314 n.10 (1990) ("[. . . ] the temptation to equate legal obligations and moral obligations might arise even in a less-than-perfect society"). See, e.g., Henry M. Hart, Jr., Comment, Holmes' Positivism - An Addendum, 64 HaRv. L. Rev. 929, 930 (1952) ("Holmes is telling us ... that we ought to see morality as the source of law rather than its content. The first part of the talk, in other words, explains what law really is - something entirely separate from morals, and the second part what it should become-something which involves morals.") (citing Mark DeWolfe Howe, The Positivism of Mr. Justice Holmes, 64 Harv. L. Rev. 529, 541-42 (1951)).

5. James Davison Hunter, Culture Wars: The Struggle to Define America 250-62 (1991).

6.

Liberty finds no refuge in a jurisprudence of doubt. Yet 19 years after our holding that the Constitution protects a woman's right to terminate her pregnancy in its early stages, Roe [...], that definition of liberty is still questioned. Joining the respondents as amicus curiae, the United States, as it has done in five other cases in the last decade, again asks us to overrule Roe.

Planned Parenthood of Se. Pa., 505 U.S. at 844 (emphasis added) (citations omitted). Further, In the present cases, however, as our analysis to this point makes clear, the terrible price would be paid for overruling. Our analysis would not be complete, however, without explaining why overruling Roe's central holding would not only reach an unjustifiable result under principles of stare decisis, but would seriously weaken the Court's capacity to exercise the judicial power and to function as the Supreme Court of a Nation dedicated to the rule of law. Id. at $864-65$.

And,

Where, in the performance of its judicial duties, the Court decides a case in such a way as to resolve the sort of intensely divisive controversy reflected in Roe and those rare, comparable cases, its decision has a dimension that the resolution of the normal case does not carry. It is the dimension present whenever the Court's interpretation of the Constitution calls the 
which remain most directly responsible to the people or masses. ${ }^{7}$ Legislators often leave contentious issues to the judiciary to solve so that they can avoid taking a stand which would alienate a large number of their constituents. ${ }^{8}$ While convenient, this raises significant concerns. United States Supreme Court Justice Antonin Scalia pointed out the absurdity in allowing the judiciary to amass such power and to decide such vitally important issues when he said in his Cruzan v. Mo. Dep't of Health concurrence,

the point at which life becomes "worthless," and the point at which the means necessary to preserve it become "extraordinary" or "inappropriate," are neither set forth in the Constitution nor known to the nine justices of this Court any better than they are known to nine people picked at random from the Kansas City telephone directory. ${ }^{9}$

contending sides of a national controversy to end their national division by accepting a common mandate rooted in the Constitution.

... But whatever the premises of opposition may be, only the most convincing justification under accepted standards of precedent could suffice to demonstrate that a later decision overruling the first was anything but a surrender to political pressure, and an unjustified repudiation of the principle on which the Court staked its authority in the first instance. So to overrule under fire in the absence of the most compelling reason to reexamine a watershed decision would subvert the Court's legitimacy beyond any serious question.

The country's loss of confidence in the Judiciary would be underscored by an equally certain and equally reasonable condemnation for another failing in overruling unnecessarily and under pressure....

The Court's duty in the present cases is clear. In 1973, it confronted the already-divisive issue of governmental power to limit personal choice to undergo abortion, for which it provided a new resolution based on the due process guaranteed by the Fourteenth Amendment. Whether or not a new social consensus is developing on that issue, its divisiveness is no less today than in 1973, and pressure to overrule the decision, like pressure to retain it, has grown only more intense. A decision to overrule Roe's essential holding under the existing circumstances would address error, if error there was, at the cost of both profound and unnecessary damage to the Court's legitimacy, and to the Nation's commitment to the rule of law. It is therefore imperative to adhere to the essence of Roe's original decision, and we do so today.

Id. at 867-69 (emphasis added). This language seems to suggest that if the societal pressure had been absent, the court would have been free to overrule, but because people vigorously protested the decision the court could not even consider looking at the plight of the unborn.

7. Delos Franklin Wilcox, Government by All the People 9 (1912). For further discussion on the branches of government accountability as well as checks and balances see The Federalist No. 51 (James Madison).

8. For example, "many members of Congress who voted for or otherwise facilitated passage of the MCA [Military Commissions Act] likely did so with the intent that, as Senator Specter said, the courts would "clean it up."' Paul A. Diller, When Congress Passes an Intentionally Unconstitutional Law: The Military Commissions Act of 2006, 61 S.M.U. L. REv. 281, 283 (2008) (footnote omitted) (quoting 152 Cong. Rec. S10263 (daily ed. Sept. 27, 2006) (statement of Sen. Specter).

9. Cruzan v. Mo. Dep't of Health, 497 U.S. 261, 293 (1990) (Scalia, J., concurring). 
Yet on the abortion issue, most of the decisions have been left to the courts which uniformly have demonstrated a lack of sensitivity towards the unborn. ${ }^{10}$

This year, in proceedings before the Grand Chamber of the European Court of Human Rights (ECHR), seventeen judges will have the chance to respect Ireland's domestic sovereignty and its constitutional amendment protecting unborn life or, in a step of judicial activism, essentially force Ireland to create a right to abortion. ${ }^{11}$ On December 9, 2009, the case was

10. For example, "Congress found, among other things, that '[a] moral, medical, and ethical consensus exists that the practice of performing a partial-birth abortion ... is a gruesome and inhumane procedure that is never medically necessary and should be prohibited." 'Gonzales v. Carhart, 550 U.S. 124, 141 (2007). And yet, the Judges upheld several equivalent procedures. Id. at 166-67; Shaun de Freitas \& Emma Finney, Modernity, the Judiciary, and Christian Benevolence Towards the Unborn, TYDSKRIFVIR Christelike Wetenskap, 1ste \& 2de Kwartaal 2010, at 30, 31. See Doe v. Bolton, 410 U.S. 179 (1973); Roe v. Wade, 410 U.S. 113 (1973); Bigelow v. Virginia, 421 U.S. 809 (1975); Singleton v. Wulff, 428 U.S. 106 (1976); Planned Parenthood of Central Missouri v. Danforth, 428 U.S. 52 (1976) (invalidated provisions prohibiting the use of saline amniocentesis abortion procedure, and requiring those performing abortions to exercise professional skill and care to preserve the life of the fetus); Colautti v. Franklin, 439 U.S. 379 (1979) (struck down a Pennsylvania statute that required physicians use the abortion technique that provided the best opportunity for the fetus to be born alive in abortions after viability); City of Akron v. Akron Center for Reproductive Health, 462 U.S. 416 (1983); Thornburgh v. American College of Obstetricians and Gynecologists, 476 U.S. 747 (1986) (invalidating provisions of a Pennsylvania statute requiring the physicians give their patients informed consent materials on fetal development and medical risks of abortion and that the physician use the method most likely to preserve the life of the a viable unborn child); Planned Parenthood of Se. Pa. v. Casey, 505 U.S. 833 (1992); Stenberg v. Carhart, 530 U.S. 914 (2000).

11. Ireland, if it chose to take extraordinary measures, technically could choose to withdraw from the Council of Europe rather than follow the court's ruling or refuse to abide by the ruling and risk expulsion by the Council of Europe. Ireland could also choose to withdraw from the European Union if that became necessary.

Article 50 of the Lisbon Treaty explicitly makes provision for the voluntary secession of a Member State from the EU. Specifically, the exit clause provides that a Member State wishing to withdraw from the EU must inform the European Council of its intention; the Council is to produce guidelines on the basis of which a withdrawal agreement is to be negotiated with that Member State; and the Council, acting by a qualified majority and after obtaining the consent of the European Parliament, will conclude the agreement on behalf of the EU. The withdrawing Member State would cease to be bound by the treaties either from the date provided for in the withdrawal agreement or, failing that, two years after notification of its intention to withdraw. Phoebus Athanassiou, Withdrawal and Expulsion from the EU and EMU: Some Reflections, 10 LEGAL WORKING PAPER SERIES 1, 23 (Dec. 2009), available at http://ssrn.com/abstract_id=1517760 (Although Ireland would hypothetically be allowed to leave, it would not be an easy process.). The process for voluntarily withdrawing from the Council of Europe is somewhat more straightforward. Under Article 7 of the Statute of the Council of Europe,

Any member of the Council of Europe may withdraw by formally notifying the Secretary General of its intention to do so. Such withdrawal shall take effect at the end of the financial year in which it is notified, if the notification is given during the first nine months of that financial year. If the notification is given in the last three months of the financial year, it shall take effect at the end of the next financial year. 
heard. As decisions of the Grand Chamber are binding on all lower courts and all member states, ${ }^{12} A$., B. and C. v. Ireland has the potential to affect policy for all Council of Europe members. ${ }^{13}$ As legal counsel from the European Centre for Law and Justice and Roger Kiska, a third party intervener in the case, pointed out "the case is not only pivotal in Europe; it is pivotal in America as well .... With ever-greater frequency, American courts have considered what other countries are doing when deciding their own cases." ${ }^{14}$ Through a comparison to the United States experience of a judicially created right to abortion, a discussion of the procedural irregularities and the lack of merit to the alleged violations of the European Convention of Human Rights, and an examination of the current absence of international law or treaties

Statute of the Council of Europe, art. 7, May 5, 1949, CETS No. 001, available at http://conventions.coe.int/treaty/en/Treaties/Html/001.htm (allowing Ireland to choose to withdraw from the Council to avoid having to comply with an ECHR ruling finding Ireland's Constitutional Amendment a violation of the European Convention of Human Rights).

12. The exception being if the ECHR chooses to issue an advisory opinion. See Basic Information on Procedures, Eur. CT. of Hum. RTs., http://www.echr.coe.int/ECHR/EN/Header/The+Court/How+the+ Court+works/Procedure+before+the+Court/ (last visited Mar. 26, 2010).

13. Tom Heneghan, Could Irish Abortion Case Lead to a "European Roe v. Wade"?, Faith WORLD (Dec. 10, 2010), http://blogs.reuters.com/faithworld/2009/12/10/could-irish-abortion-case-lead-toa-european-roe-v-wade/ ("the decision will . . . be a landmark event because it could set a precedent on whether access to abortion is a basic human right in Europe"); Hilary White, Human Rights Court Case Could Be Europe's Roe. v. Wade, LifeSiteNews.com (July 14, 2009), http://www.lifesitenews.com/ ldn/2009/jul/09071406.html.

14. White, supra note 13; see, e.g., Graham v. Florida, 130 S. Ct. 2011 (2010); Roper v. Simmons, 543 U.S. 551 (2005); Lawrence v. Texas, 539 U.S. 558 (2003); Atkins v. Virginia, 536 U.S. 304 (2002); Washington v. Glucksberg, 521 U.S. 702 (1997); Miranda v. Arizona, 384 U.S. 436 (1966); Trop v. Dulles, 356 U.S. 86 (1958). The confirmation of Elena Kagan only increases the expectancy that the Supreme Court will continue to rely on international law as in her confirmation hearings she stated that "[t]here are some cases in which the citation of foreign law, or international law, might be appropriate," in response to a question from Sen. Chuck Grassley. Confirmation Hearing on The Nomination of Elena Kagan to be an Associate Justice of the Supreme Court of the United States: Hearing Before the Sen. Comm. on the Judiciary, 111th Cong. (forthcoming 2011), available at http://www.lexisnexis.com (search "Kagan nomination" for "June 29, 2010" under "CQ transcriptions" database). Grassley continued: "If confirmed, would you rely on or cite international foreign law when you decide cases?" Id. She added that she is "in favor of good ideas coming from wherever you can get them" and said "there are a number of circumstances" when foreign law might be appropriate. $I d$. Her appointment increases the chances that if an international right to abortion is found in $A$., $B$ and $C v$. Ireland the court may use that precedent in reconsidering a case about whether indigent women have a Constitutional right to federally funded abortions. Justice Ginsburg commented in a recent interview about her belief that Roe was originally "going to be then set up for Medicaid funding for abortion" and her belief that reproductive choice needs to be straightened out so that there is not a policy which only affects poor women. Emily Bazelon, The Place of Women on the Court, N.Y. Times, July 12, 2009, at MM22. One of Kagan's judicial heroes Justice Thurgood Marshall stated in his dissent to Harris v. McRae, "that denial of a Medicaid-funded abortion is equivalent to denial of legal abortion altogether." 448 U.S. 297, 338 (1980). 
recognizing a right to abortion, this article will present a case for the wisdom of judicial restraint and respect for the margin of appreciation doctrine.

\section{The Human Faces to the Case Produce an Emotional Response to THE ISSUE}

At stake in this international case is Ireland's constitutional amendment protecting unborn life. The Court will have to decide whether the amendment, which renders the plaintiffs effectively unable to terminate their pregnancies within Ireland, infringes on the plaintiffs' human rights under the European Convention of Human Rights. However, courts rarely examine laws in a vacuum. There must be a case and controversy in order to be heard. ${ }^{15}$ A party must challenge a law based on an experience in order to raise an issue. ${ }^{16}$ It is the recitation of the human stories that tug at the heartstrings and illustrate the hardships these three particular women faced in their decisions to terminate their pregnancies.

Due to the facts' emotive appeal to the media, and indeed to the judges hearing the case, it is important to keep the facts in mind when considering the case. Interestingly, one of the three applicants in the case is not Irish. The applicants are two female Irish nationals and one female Lithuanian national who resides in Ireland. ${ }^{17}$ All three of the applicants in this case allege that they became pregnant unintentionally, ${ }^{18}$ but otherwise each has a unique story to tell.

The first applicant, A, was a recovering alcoholic, unmarried, unemployed, and impoverished mother of four. ${ }^{19}$ She had recently reestablished contact with her four children who were in foster care and feared that a new sibling would endanger the reunification of her family. ${ }^{20}$ Therefore, she made the decision to travel to England and procure an abortion there, overcoming the hurdles of insufficient funds, international travel, and doing

15. The European Convention for the Protection of Human Rights and Fundamental Freedoms, as amended by Protocol No. 11, arts. 34-36, ratified Nov. 1, 1998, 213 U.N.T.S. 221 [hereinafter European Convention on Human Rights], available at http://conventions.coe.int/Treaty/en/Treaties/Html/005.htm.

16. $I d$.

17. Statement of Facts at The Facts $\S(A)(1), A$., B. and C., App. No. 25579/05.

18. Id. $\S \S \mathrm{A}(1)-(3)$. A consultant in the case, William Saunders pointed out that the reference to the unintentional nature of the pregnancies is surprising, writing, "What relevance is the 'intent' to create a human being to Ireland's right to protect its life once created?" William Saunders, The Roe v. Wade of Europe, NAT. Rev. Online (Dec. 9, 2009), http://www.nationalreview.com/bench-memos/49423/i-roe-i-vi-wade-i-europe/william-saunders.

19. Statement of Facts at The Facts $\S \mathrm{A}(1), A$., B. and C., App. No. 25579/05.

20. Id. 
it secretly "without missing a contact visit with her children." ${ }^{21}$ Upon her return, she experienced "pain, nausea and bleeding for eight to nine weeks.",22 Knowing about the prohibition on abortion, she feared contacting a doctor for medical advice. ${ }^{23}$ Despite her concerns, she was treated without incident at an Irish hospital for an incomplete abortion and underwent a dilation and curettage. ${ }^{24}$ Dissatisfied with current Irish law, A brought suit before the ECHR.

The second applicant, B, was single and at risk for an ectopic pregnancy ${ }^{25}$ when she decided to travel to England to obtain an abortion. ${ }^{26}$ Her risk for an ectopic pregnancy developed as a common side effect of the failure of the "morning after pill" emergency contraception $\mathrm{B}$ had taken. ${ }^{27} \mathrm{~B}$ admits that by the time she had her abortion, she knew that she did not in fact have an ectopic pregnancy, and that her decision to have an abortion was made prior to learning of the possible medical condition. ${ }^{28}$ Upon her return to Ireland she "started passing blood clots," but, afraid to seek medical advice in Ireland, she returned to England for a medical exam. ${ }^{29}$ Despite her alleged fear, B also received follow-up care at a Dublin clinic without incident. ${ }^{30} \mathrm{~B}$ alleges that "the impossibility for her to have an abortion in Ireland made the procedure unnecessarily expensive, complicated and traumatic." ${ }^{\prime 1}$ Therefore, she brought suit to the ECHR.

The third applicant, $\mathrm{C}$, was a cancer patient whose cancer had gone into remission..$^{32}$ Before becoming aware of her pregnancy, $\mathrm{C}$ underwent a series of tests to determine her state of health, which could have affected the fetus. ${ }^{33}$

\footnotetext{
21. Id.

22. Id.

23. $I d$.

24. Applicants' Reply to the Observations of Ireland on the Admissibility and Merits at 4, A., B. and C. v. Ireland, App. No. 25579/05 (Eur. Ct. H.R. filed on Dec. 23, 2008).

25. In an ectopic pregnancy the fetus develops outside the uterus. American Heritage Dictionary 438 (Mark Boyer et al. eds., 2d ed. 1985).

26. Statement of Facts at The Facts $\S \mathrm{A}(2), A$., B. and C., App. No. 25579/05.

27. Id.; see generally Gary Culliton, Doctors Advised on Morning-After Pill, Irish Medical Times (Apr. 27, 2009), http://www.imt.ie/news/medico-legal/2009/04/doctors-advised-on-morning-after-pill.html (explaining that emergency contraception is available in Ireland for adults, though a doctor's general prescription is required and that Irish courts are moving toward a standard which would allow women as young as sixteen to obtain a prescription).

28. Applicants' Reply at 5, A., B. and C., App. No. 25579/05.

29. Statement of Facts at The Facts $\S \mathrm{A}(2), A$., B. and C., App. No. 25579/05.

30. Applicants' Reply at 5, A., B. and C., App. No. 25579/05.

31. Statement of Facts at The Facts $\S \mathrm{A}(2), A$., B. and C., App. No. 25579/05.

32. Statement of Facts at The Facts $\S \mathrm{A}(3), A$., B. and C., App. No. 25579/05.

33. Id.
} 
Unable to find a doctor who would make a determination that her life was at risk if the pregnancy continued and uncertain of the potential damage to the fetus, she chose to go to England for an abortion..$^{34}$ The United Kingdom would not assist her in a medical abortion due to the need for follow-up medical care, so $\mathrm{C}$ waited eight weeks in order to be eligible for a surgical abortion causing her "emotional distress and fear for her health." ${ }^{35}$ Upon her return to Ireland, $\mathrm{C}$ suffered "the complications of an incomplete abortion, including prolonged bleeding and infection. ${ }^{, 36}$ After the experience, $\mathrm{C}$ chose to sue in the ECHR.

When read together, these three stories put a face on the very real cost to women imposed by Ireland's constitutional amendment protecting unborn life. If their stories are framed in the light most favorable to their point of view-a recovering alcoholic struggling to put her life back on track to care for her four young children, a single woman alone facing a risky ectopic pregnancy, and a courageous cancer survivor battling for her life and simultaneously worrying about the damage she may have already unwittingly caused the fetus - they create a compelling tale of the struggles of Irish women unwillingly or unintentionally pregnant. Yet, is the cost to Irish women prohibitively high?

Do their hardships rise to a level which violates their basic human rights under the European Convention of Human Rights? Is this a case where it is necessary for the Grand Chamber of the ECHR to intervene with Ireland's domestic policy and overturn a constitutional amendment put in place by referendum in 1983, irrevocably altering Ireland's prolife policies, and simultaneously creating an international precedent of a right to abortion for all Council of Europe Member States?

When answering the above questions, it is important to remember that the three women's lives are not the only ones in the case. There are three additional faces in this case that Ireland would have the ECHR recognize and Ireland finds their stories compelling. ${ }^{37}$ For the purposes of this article they

34. Id.

35. Id.

36. Id.

37. In fact Ireland finds the protection of the unborn so compelling that they passed a Constitutional Amendment guaranteeing the unborn absolute protection throughout pregnancy within Ireland's borders unless there is a risk to the life of the mother. See IR. Const., 1937, art. 40.3.3 (amended 1983), available at http://www.taoiseach.gov.ie/eng/Youth_Zone/About_the_Constitution,_Flag,_Anthem_Harp/ Constitution_of_Ireland_March_2010.pdf(last visited Oct. 13, 2010). Additionally, Ireland's government is vigorously defending its Constitution in this case and seeking to prevent the proposed Council of Europe resolution, "Access to Safe and Legal Abortion." See Observations of Ireland on the Third Party 
will be referred to as D, E, and F. They are the three fetuses whose lives were abruptly and tragically brought to an end by A, B, and C's individual decision to procure an abortion. Ireland's Constitution mandates that their right to life be respected, considered, and balanced with the women's hardships. ${ }^{38}$ The provision reads, "[ $t]$ he State acknowledges the right to life of the unborn and, with due regard to the equal right to life of the mother, guarantees in its laws to respect, and, as far as practicable, by its laws to defend and vindicate that right." ${ }^{39}$ Ireland's provision struggles to balance the rights of the unborn person and the mother while recognizing that the basic right to life enshrined in Article 2 of the European Convention on Human Rights takes primacy over all other rights. Ireland's conception of the unborn considers six sympathetic individuals in the case instead of limiting its scope to only the three women. As that is a decision that widens and broadens protections and maintains the historical understanding of human life, it is a decision that should be respected. ${ }^{40}$

If Ireland was choosing to limit or narrow the definition of life by, for instance, adopting philosopher Peter Singer's definition of what type of human life warrants protection with a constitutional amendment, the ECHR would be more than justified in intervening to correct Ireland's exclusion of infants and the disabled from the list of persons entitled to life. ${ }^{41}$ The Court's intervention in such a situation would be consistent with the worldwide trend towards universal protection of human life and the elimination of

Observations at 3-7, appendix A and B, A., B. and C. v. Ireland, App. No. 25579/05 (Eur. Ct. H.R., Dec. 19, 2008).

38. IR. Const., 1937, art. 40.3 .3 (amended 1983), available at http://www.taoiseach.gov.ie/ eng/Youth_Zone/About_the_Constitution,_Flag,_Anthem_Harp/Constitution_of_Ireland_March_2010.pdf (last visited Oct. 13, 2010).

39. Id.

40. See European Convention of Human Rights, supra note 15, art. 53 ("Safeguard for Existing Human Rights: Nothing in this Convention shall be construed as limiting or derogating from any of the human rights and fundamental freedoms which may be ensured under the laws of any High Contracting Party or under any other agreement to which it is a Party.").

41. Peter Singer describes his logic about infants: "Human babies are not born self-aware or capable of grasping their lives over time. They are not persons. Hence their lives would seem to be no more worthy of protection than the life of a fetus." Peter Singer, Rethink ing Life And DeAth: The Collapse of Our Traditional Ethics 210 (Oxford Univ. Press 1995) (1994). When Singer was confronted by a disabled advocacy group "[a]t a Princeton Forum, Singer remarked that he would have supported the parents of his disabled protestors if they had sought to kill their disabled offspring in infancy." DONALD DE MARCo \& Benjamin Wiker, Architects of the Culture of Death 371 (2004). See also Michael Tooley, ABORTION AND INFANTICIDE 411 (1983) ("New-born humans are neither persons nor even quasi-persons, and their destruction is in no way intrinsically wrong."). 
discrimination..$^{42}$ Why the Court should intervene to refuse Ireland's protection of biologically human fetuses' right to life is far less easy to determine and indeed is arguably an indefensible position.

\section{The Women's Hardships Are Not a Violation of the European Convention of Human Rights}

These three women allege that Ireland's Constitutional Amendment which effectively prevents them from procuring an elective abortion in Ireland $^{43}$ violates their basic human rights and thus the European Convention of Human Rights. Specifically, the women allege violations of four provisions of the Convention: the right to bodily integrity and privacy, the right to be free from torture or degrading treatment, the right to life, and the prohibition of discrimination. ${ }^{44}$ I argue that each and every claim fails on its merits as none of the claims rise to the level of European Convention of Human Rights protections.

42. See, e.g., U.N. Charter art. 2, para. 4; Statute of the International Tribunal, art. 2, May 25, 1993, 32 I.L.M. 1192; European Human Rights Convention, supra note 15; Records of the UNESCO General Conference, Paris, Fr., Oct. 21-Nov. 7, 1997, Declaration on the Responsibilities of the Present Generation towards the Future Generation, vol. 1 Resolutions, 69-71; International Convention on the Protection of the Rights of all Migrant Workers and Members of their Families, Dec. 18, 1990, 2220 U.N.T.S. 93; Convention on the Rights of the Child, Nov. 20, 1989, 1577 U.N.T.S. 3; United Nations Convention Against Torture and Other Cruel, Inhuman or Degrading Treatment or Punishment, Dec. 10, 1984, 1465 U.N.T.S. 85; Convention on the Elimination of all Forms of Discrimination against Women, Dec. 18, 1979, 1249 U.N.T.S. 13; Organization of American States, American Convention on Human Rights, Nov. 22, 1969, O.A.S.T.S. No. 36, 1144 U.N.T.S. 123; International Covenant on Civil and Political Rights, Dec. 16, 1966, 999 U.N.T.S. 171; International Covenant on Economic, Social, and Cultural Rights, Dec. 16, 1966, U.N.T.S. 3; International Convention on the Elimination of all forms of Racial Discrimination, Mar. 7, 1966, 660 U.N.T.S. 195; Geneva Convention Relative to the Treatment of Prisoners of War, art. 3, Aug. 12, 1949, 6 U.S.T. 3316; Universal Declaration of Human Rights, G.A. Res. 217(III)A, U.N. Doc. A/810 at 71 (1948).

43. Doctors are clearly authorized to perform abortions in Ireland when the life of the mother is at stake. See, e.g., The Attorney General v. X, [1992] 1 I.R. 1 (Ir.); McGee v. The Attorney General, [1974] I.R. 284 (Ir.). See also Medical Council, A Guide to Ethical Conduct and Behaviour § 24.6 (2004) ("The Council recognises that termination or pregnancy can occur when there is real and substantial risk to the life of the mother....").

44. European Convention on Human Rights, supra note 15, art. 3 (declaring the right to be free from inhumane and degrading treatment); $i d$. art. 2 (declaring the right to life); $i d$. art. 8 (declaring the right to privacy); $i d$. art. 14 (declaring equal treatment under the Convention regardless of sex or status). 


\section{A. The Applicants' Article 8 Claims Fail}

First, the women allege that their right to privacy in all family, home, and personal interests was violated, and that Ireland's abortion ban interferes with their entitlement to freedom from public interference from any public authority in exercising this right. ${ }^{45}$ The women also listed in their complaint that:

$[\mathrm{T}]$ he national law on abortion was not sufficiently clear and precise, since the Constitutional term "unborn" was vague and since the criminal prohibition was open to different interpretations. The fact that it was open to women - provided they had sufficient resources - to travel outside Ireland to have an abortion defeated the aim of the restriction and the fact that abortion was available in Ireland only in very limited circumstances was disproportionate and excessive. ${ }^{46}$

In the Grand Chamber of the ECHR's response to this count of the complaint, the Grand Chamber reframed the claim by requesting the parties prepare arguments on whether "in the particular circumstances of each applicant's case, did the national legal position concerning abortion interfere with her rights under Article 8 of the Convention? If so, was the interference provided for by law, did it pursue a legitimate aim and was it proportionate to that aim?" ${ }^{47}$ I argue, based on the following paragraphs, that the Irish law is proportionate to the legitimate aim. It is noteworthy that the ECHR has concluded in earlier cases that, "the protection in Ireland of the right to life of the unborn both" serve a "legitimate aim" and are proportionally tailored and necessary in a democratic society. ${ }^{48}$

Ireland responds to the women's complaint by observing that the Article 8 guarantee is not absolute within the context of pregnancy, and that by definition pregnancy is not a wholly private matter. ${ }^{49}$ Indeed, the ECHR has recognized the limitation on Article 8 within the context of pregnancy in prior

45. European Convention on Human Rights, supra note 15, art. 8.1 ("Everyone has the right to respect for his private and family life, his home and his correspondence."); id. art. 8.2 ("There shall be no interference by a public authority with the exercise of this right except such as is in accordance with the law and is necessary in a democratic society in the interests of national security, public safety or the economic well-being of the country, for the prevention of disorder or crime, for the protection of health or morals, or for the protection of the rights and freedoms of others.").

46. Statement of Facts at Complaints, A., B. and C., App. No. 25579/05.

47. Statement of Facts at Questions to the Parties § 2, A., B. and C., App. No. 25579/05.

48. Open Door and Dublin Well Woman v. Ireland, 246 Eur. Ct. H.R. (ser. A) at 27 (1992); Joint Written Observations of Third Party Interveners at 7, A., B. and C. v. Ireland, App. No. 25579/05 (Eur. Ct. H.R., Nov. 14, 2008) [hereinafter Observations of Third Party Interveners].

49. Observations of Third Party Interveners, supra note 48, at 6 . 
case law. ${ }^{50}$ Applying the margin of appreciation doctrine then, the ECHR is to give sovereign states leeway in allowing their national authorities to determine the circumstances warranting restrictions on guaranteed rights. ${ }^{51}$ Ireland's view of the right to life places both the woman and the child in the pregnancy on equal footing and deference to Ireland's decision that the Article 2 right to life justifies a limitation with adequate safeguards on the woman's Article 8 right should "outweigh[ ] any alleged conflicts with the interests of women to health, privacy and bodily integrity." ${ }^{, 2}$ Although perhaps not as strong of an argument, Ireland could also point to the growing recognition that the long term aftereffects of abortion can have a negative effect on women and thus Ireland, by banning abortions, is protecting the women's health. ${ }^{53}$ The ECHR should consider Ireland's attempt to balance privacy and health when deciding whether Ireland violates the women's Article 8 right.

If the ECHR should determine that Ireland's national position on abortion interfered with the women's Article 8 right, then the second question will be addressed. The Court will need to determine whether "Ireland's restriction on

50. See, e.g., Vo v. France, App. No. 53924/00, 40 Eur. H.R. Rep. 12, 80 (2005) (“[T]he issue has always been determined by weighing up various, and sometimes conflicting, rights or freedoms claimed by a woman, a mother or a father in relation to one another or vis-à-vis an unborn child."); Brüggemann and Scheuten v. Fed. Republic of Germany, App. No. 6959/75, 3 Eur. H.R. Rep. 244, 25354 (1977) ("Article $8 \S 1$ cannot be interpreted as meaning that pregnancy and its termination are, as a principle, solely a matter of the private life of the mother.").

51. See Kruslin v. France, 176 Eur. Ct. H.R. 1 (ser. A) at 24-25. See also Evans v. United Kingdom, App. No. 6339/05, 43 Eur. H.R. Rep. 21, 77 (2007) (“A number of factors must be taken into account when determining the breadth of the margin of appreciation to be enjoyed by the State in any case under Article 8. Where a particularly important facet of an individual's existence or identity is at stake, the margin allowed to the State will be restricted (see, for example, $X$. and $Y$. v. the Netherlands, judgment of 26 March 1985, Series A no. 91, $\S \S 24$ and 27; Dudgeon v. the United Kingdom, judgment of 22 October 1981, Series A no. 45; Christine Goodwin v. the United Kingdom [GC], no. 28957/95, § 90, ECHR 2002-VI; cf. Pretty, cited above, § 71). Where, however, there is no consensus within the Member States of the Council of Europe, either as to the relative importance of the interest at stake or as to the best means of protecting it, particularly where the case raises sensitive moral or ethical issues, the margin will be wider $(X ., Y$. and $Z$. v. the United Kingdom, judgment of 22 April 1997, Reports of Judgments and Decisions 1997-II, § 44; Frette v. France, no. 36515/97, § 41, ECHR 2002-I; Christine Goodwin, cited above, § 85; see also mutatis mutandis, Vo, cited above, $\S 82$ ). There will also usually be a wide margin if the State is required to strike a balance between competing private and public interests or Convention rights (see Odièvre, §§ 44-49 and Frette § 42)."); Huvig v. France, 176 Eur. Ct. H.R. 36 (ser. A) at 52-53 (1990); Handyside v. United Kingdom, App. No. 5493/72, 1 Eur. H.R. Rep. 737, $48-49$ (1976), available at http://www.echr.coe.int/ ECHR/EN/hudoc.; Jean-Francois Renucci, Droit Europeen des droits de L'homme 329 (LGDJ/Montchrestien 2002) (1999).

52. Observations of Third Party Interveners at 6, A., B. and C., App. No. 25579/05.

53. Gonzales v. Carhart, 550 U.S. 124, 159 (2007) ("[I]t seems unexceptionable to conclude some women come to regret their choice to abort the infant life they once created and sustained. . . . Severe depression and loss of esteem can follow.") (citations omitted). 
abortion is prescribed by law, is precise enough and reasonably foresees its consequences, and provides adequate safeguards against arbitrary interference with respective substantive rights." ${ }^{54}$ There is no dispute that Ireland's restrictions on abortion are prescribed by law. ${ }^{55}$ The Irish law must also pursue a legitimate aim which is proportional to its necessity in a democratic society and its ability to meet a pressing social need. ${ }^{56}$ In fact, the applicants expressly concede that "the State's action was in accordance with the law, and had a legitimate aim of protecting fetal life." "Th "The laws must be based on just reasons which are relevant, sufficient, ${ }^{58}$ and concrete." ${ }^{59}$ Restrictions on abortion are compatible with the requirements of a democratic society. ${ }^{60}$ Prevention of abortion can also include the protection of the health, bodily integrity, and privacy of women. ${ }^{61}$ Although occasionally presumed, it is not a foregone conclusion that legalized abortion necessarily results in the improved health of women. ${ }^{62}$ Numerous studies by mainstream health

54. Observations of Third Party Interveners at 6, A., B. and C., App. No. 25579/05; cf. Huvig v. France, 176 Eur. Ct. H.R. 36 (ser. A) at 52-53 (1990); Kruslin v. France, 176 Eur. Ct. H.R. 1 (ser. A) at $24-25$.

55. IR. Const., 1937, art. 40.3; Offences Against the Person Act, 1861, 24-25 Vict., c. 100 \$ 58-59 (Ir.); Civil Liability Act $\S 58$ (No. 41/1961) (Ir.), available at http://www.irishstatutebook.ie/1961/en/ act/pub/0041/index.html; Health (Family Planning) Act $\S 10$ (No. 20/1979) (Ir.), available at http://www.irishstatutebook.ie/1979/en/act/pub/0020/index.html.

56. Observations of Third Party Interveners at 6, A., B. and C., App. No. 25579/05; cf. Sunday Times v. United Kingdom, App. No. 6538/74, 2 Eur. H.R. Rep. at 278-79 et seq. (1979).

57. Applicants' Reply at 24, A., B. and C., App. No. 25579/05.

58. Dudgeon v. United Kingdom, App. No. 7525/76, 4 Eur. H.R. Rep. 149, 164 (1979).

59. Observations of Third Party Interveners at 6, A., B. and C., App. No. 25579/05.

60. Observations of Third Party Interveners at 8, A., B. and C., App. No. 25579/05 ("[Sixty-eight] countries worldwide prohibit abortion entirely or allow it only to save the mother's life."). The 68 include four other signatories of the European Convention on Human Rights. Also, there is no internationally recognized right to abortion in existence in international law or treaty. "Pro-abortion groups cannot find an international right to abortion and so are forced to cite only non-binding, ungratified interpretations by unelected compliance committees. These carry no weight." Id. at 9.

61. An additional factor to consider is the

question of which women's health counts in the calculus. Somewhat more than half of the unborn children killed in abortion are women. . . [A]11 over the world and increasingly in Western nations, female unborn children are selected for abortion precisely because they are women and not men, in a practice that the UNFPA calls "female infanticide."

Observations of Third Party Interveners at 9, A., B. and C., App. No. 25579/05; United Nations, Report of the International Conference on Population and Development (1995), http://www.unfpa.org/public/ home/sitemap/icpd/International-Conference-on-Population-and-Development/ICPD-Programme.

62. Ireland's maternal mortality rate is the lowest in Europe, while the rate is three times higher in England, which has very liberal abortion laws. See Niall Hunter, Ireland's Death Rates Improving, http://www.irishhealth.com/index.html?level=4\&id=13789 (last visited Oct. 6, 2010). See World Health Organization, Maternal Mortality in 2005: Estimates Developed by WHO, UNICEF, UNFPA, and the World Bank 23-27 (2007), available at http://whqlibdoc.who.int/publications/2007/ 
professionals, governments, and universities link abortion to increased health risks for women. ${ }^{63}$

The ECHR has concluded in earlier cases that the protections afforded to the unborn serve a "legitimate aim" and can be proportionally tailored and necessary in a democratic society. ${ }^{64}$ Even more damaging to A, B, and C's claim is that Article 8 of the Convention states,

[t] here shall be no interference by a public authority with the exercise of this right except such as is in accordance with the law and is necessary in a democratic society in the interests [. . . ] for the protection of health or morals, or for the protection of the rights and freedoms of others. ${ }^{65}$

This provision notes that there are recognized exceptions to Article 8. The ECHR has previously commented on its determination that the Irish protection of the unborn qualifies as a legitimate aim, and a potential exception for the protection of health and morals under Article 10, and presumably a potential exception under Article 8 which mirrors its language. ${ }^{66}$ The prohibition on abortion also falls under the last exception as it serves to protect the rights and freedoms of the unborn who qualify as "others" under Irish law. ${ }^{67}$ In ECHR history it is not unusual for the Court to recognize extensive exceptions to the

9789241596213_eng.pdf. A New Zealand 25-year longitudinal study found that young women "having an abortion had elevated rates of subsequent mental health problems including depression, anxiety, suicidal behaviours and substance use disorders. This association persisted after adjustment for confounding factors." D.M. Fergusson et al., Abortion in Young Women and Subsequent Mental Health, 47 J. CHILD Psychol. \& Psychiatry 16, 16 (2006). An international study conducted in 2004 showed that the death rate from abortion was "three times higher in Finland and 1.6 to 2 times higher in California, than the death rate from childbirth." Observations of Third Party Interveners at 10, A., B. and C., App. No. 25579/05. See Mika Gissler et al., Pregnancy-Associated Mortality After Birth, Spontaneous Abortion or Induced Abortion in Finland, 1987-2000, 190 Am. J. OBstetrics \& Gynecology 422, 422 (2004). David C. Reardon et al., Deaths Associated with Abortion Compared to Childbirth: A Review of New and Old Data and the Medical and Legal Implications, 20 J. Contemp. Health L. \& Pol'y 279, 280 (2004). Abortion also causes a risk to the mother and child in subsequent pregnancies. Brent Rooney, Induced Abortion and Risk of Later Premature Births, 8 J. Am. Physicians. \& Surgeons 46, 46 (2003).

63. See note supra 62.

64. Open Door and Dublin Well Woman v. Ireland, 246 Eur. Ct. H.R. (ser. A) 8, 27 (1992); Observations of Third Party Interveners at 7, A., B. and C., App. No. 25579/05.

65. European Convention on Human Rights, supra note 15, art. 8 (emphasis added).

66. The ECHR concluded,

[T] hat the protection afforded under Irish law to the right of life of the unborn is based on profound moral values concerning the nature of life which were reflected in the stance of the majority of the Irish People against abortion as expressed in the 1983 referendum. The restriction thus pursued the legitimate aim of the protection of morals of which the protection in Ireland of the right to life of the unborn is one aspect.

Open Door and Dublin Well Woman, 246 Eur. Ct. H.R. (ser. A) at 27.

67. Observations of Third Party Interveners at 8, A., B. and C., App. No. 25579/05. 
right to privacy. ${ }^{68}$ Protection of the unborn is arguably a compelling reason for recognition. Ultimately, the restrictive law must be held to be proportional to the legitimate aim pursued, or "the achievement of a fair balance between the various conflicting interests." Under existing ECHR case law, Ireland's approach is sufficiently balanced between the competing interests.

The women also assert that the ban fails because it is imprecise in its language and unreasonable in accommodating women's health concerns. ${ }^{70}$ However, by relying upon and deferring to recognized and accepted medical guidelines, the law achieves the necessary precision. Irish case law and the Irish Medical Council guidelines both recognize that termination may occur where the risk of death is both real and substantial. ${ }^{71}$ Relying to an extent on a doctor's clinical judgment as to when a particular life is in danger is more sensible than trying to craft a legislative rule which would attempt to create universally applicable guidelines that would work in highly individual and unique situations. ${ }^{72}$ The ECHR has recognized that "it is not its function to question the doctors' clinical judgment as regards the seriousness of the first applicant's condition or the appropriateness of the treatment they proposed." 73 Given the specific nature of the Irish law and its accompanying medical guidelines this challenge would seem to fail in the face of the evidence.

\section{B. The Applicants' Article 3 Claim Is Without Merit}

Second, the women claim that the ban on abortion violates their right to be free from inhumane and degrading treatment (Article 3) because allegedly, women seeking abortions in Ireland are stigmatized and suffer increased feelings of guilt, as well as difficulty securing follow-up care. ${ }^{74}$ The ECHR

68. The Court has recognized privacy exceptions with regard to physical integrity, sexual activity, and gender rights. See, e.g., A.D.T. v. the United Kingdom, 2000-IX Eur. Ct. H.R. 295; Sheffield and Horsham v. United Kingdom, 1998-V Eur. Ct. H.R. 2011 (1998); Cossey v. United Kingdom, 184 Eur. H.R. (ser. A) at 1 (1990); Rees v. the United Kingdom, App. No. 9532/81, 9 Eur. H.R. Rep. 56 (1986); McFeeley v. United Kingdom, 3 Eur. H.R. Rep. 161 (1980).

69. See also Dudgeon v. United Kingdom, 4 Eur. H.R. Rep. 149, 167 (1981); Handyside v. United Kingdom, App. No. 5493/72, 1 Eur. H.R. Rep. 737, 49 (1976), available at http://www.echr.coe.int/ ECHR/EN/hudoc.

70. Statement of Facts at Complaints, A., B. and C., App. No. 25579/05.

71. See The Attorney General v. X, [1992] 1 I.R. 1 (Ir.); McGee v. The Attorney General, [1974] I.R. 284 (Ir.); Medical Council, A Guide to Ethical Conduct and Behaviour § 24.6 (2004) ("The Council recognises that termination or pregnancy can occur when there is real and substantial risk to the life of the mother. ...").

72. Observations of Third Party Interveners at 7-8, A., B. and C., App. No. 25579/05.

73. Glass v. United Kingdom, 2004-II Eur. Ct. H.R. 25, 49.

74. European Convention on Human Rights, supra note 15, art. 3 ("No one shall be subjected to 
asked for clarification about any issues arising under Article 3, suggesting perhaps that the Court found the petitioners' complaint to be insufficient or vague. ${ }^{75}$ The petitioners are essentially claiming that the refusal of elective abortion services and the law protecting unborn life are tantamount to torture, inhumane, and degrading treatment under the United Nations Convention against Torture and Other Cruel, Inhuman or Degrading Treatment or Punishment (CAT) ${ }^{76}$ Thus, upon perusal of the Convention's definitions, it is readily understood why the Court requested clarification of the petitioners' argument.

The necessary elements to constitute torture, inhumane, or degrading treatment have been set out in the CAT and adopted by the ECHR. ${ }^{77}$ The elements are: the infliction of severe mental or physical pain; the intentional or deliberate infliction of pain; and the pursuit of a specific purpose such as gaining information, punishment or intimidation. ${ }^{78}$ The ECHR has expanded the standard of inhumane or degrading treatment to ask if the treatment was "deliberately causing severe suffering, mental or physical, which in a particular situation is unjustifiable." 79 It is telling that the ECHR found no violation of Article 3 when an applicant was prevented from obtaining an abortion by Polish law even when the result was a deterioration of the woman's vision. ${ }^{80}$ The Court has also held "that the object of the treatment complained of must have as its object, the purpose of humiliation and debasement of the applicants. ${ }^{\prime 81}$ It is difficult to find a rational argument that the purpose of Ireland's pro-life policy is to humiliate or debase Irish women. Outside of protecting the life of the mother, abortion is an elective procedure and denial of an elective abortion should not be considered denial of essential healthcare. ${ }^{82}$ Pregnant women are not detained if they wish to travel abroad to

torture or to inhuman or degrading treatment or punishment.”).

75. Statement of Facts at Questions to the Parties $\S 4, A$., B. and C., App. No. 25579/05.

76. United Nations Convention Against Torture and Other Cruel, Inhuman or Degrading Treatment or Punishment, Dec. 10, 1984, 1465 U.N.T.S. 85, available at http://www.unhcr.org/refworld/docid/ 3ae6b3a94.html [hereinafter CAT].

77. See id. art. 1; Akkoc v. Turkey, 2000-X Eur. Ct. H.R. 389, 426; Salman v. Turkey, 2000-VII Eur. Ct. H.R. 365, 400.

78. CAT, supra note 76, art. 1.

79. The Greek Case, 12 Yr. bk. Eur. Ct. of H.R. 1 (1969).

80. Tysiac v. Poland, App. No. 5410/03, 2007 Eur. Ct. H.R. $§ 65$ 66, http://www.unhcr.org/ refworld/docid/470376112.html.

81. Observations of Third Party Interveners at 14, A., B. and C., App. No. 25579/05; The Greek Case, at 196.

82. Observations of Third Party Interveners at 14-15, A., B. and C., App. No. 25579/05. 
procure an abortion and abortion is allowed to save a mother's life.$^{83}$ It is the official policy of medical community of Ireland to "provide abortion aftercare." $"$ Thus any concerns about the availability of post abortion care in Ireland fail on a factual level unless evidence of a pattern of refusal of access to such care can be established. Evidence has not shown that pattern, as even applicants A and B admitted that they received abortion aftercare in Ireland without any legal or criminal consequences ${ }^{85}$ Based on the above factors it is hard to characterize Ireland's behavior as deliberately causing suffering with severity or intensity. The fact that a woman feels uncomfortable pursuing the options Ireland has provided is not justification for overturning a legal proscription. The Intervener's brief makes an excellent point when it states that:

[T] o show that Ireland has the requisite intent to commit torture, inhuman or degrading treatment, Irish authorities would at least need to be aware that a particular woman had or is seeking an abortion. Allowing a mere omission to constitute torture or inhuman treatment would constitute a slippery slope that inalterably undermines the Convention and its purposes. ${ }^{86}$

The woman may feel humiliated or guilty, but Ireland's actions do not seek to promote or encourage her feelings of guilt and shame. Thus, its actions do not constitute degrading or inhumane torture, and so the Article 3 claim should also fail.

\section{Applicant C's Article 2 Claim Also Fails}

Third, the allegation is brought by $\mathrm{C}$ alone that the ban on abortion breaches her right to life (Article 2) because the Irish government has not provided any clear legislation about when abortion may be legally carried out under the exception reserved for saving the mother's life, which placed her

83. IR. CONST., 1937, art. 40.

84.

The Irish Medical Council's Guide to Ethical Conduct and Behaviour itself makes absolutely clear that: "we recognize our responsibility to provide aftercare for women who decide to leave the State for termination of pregnancy. We recommend that full support and follow up services be made available for all women whose pregnancies have been terminated, whatever the circumstances."

Observations of Third Party Interveners at 15 n.66, A., B. and C., App. No. 25579/05; MediCal Council, A Guide to Ethical Conduct and Behaviour $\S 2.5$ (2004).

85. Applicants' Reply at 4-6, A., B. and C., App. No. 25579/05.

86. Observations of Third Party Interveners at 15, A., B. and C., App. No. 25579/05. 
life in danger ${ }^{87}$ The ECHR inquired into whether any issue arose under Article 2 during the oral arguments. ${ }^{88}$

Under Article 2 the state has a positive obligation to provide health care to an individual when it has undertaken to make a certain type of health care widely available to the population. ${ }^{89}$ Abortion is not provided in Ireland except when the life of the mother is at stake, so Ireland has no positive obligation to provide abortion services to its citizens. The ECHR has already resolved that negative claims that government inaction would violate a petitioner's right to life cannot be considered separately from an Article 3 claim. ${ }^{90}$ There is clearly a legislative exception built into the Irish Constitution allowing doctors to perform abortions to save the life of a mother. ${ }^{91}$ This exception is invoked by independent medical judgment and justly recognizes that potential medical conditions are fact specific and legislation cannot (and should not) attempt to adequately address all possible scenarios. As such, the invocation of the exception is appropriately left in the hands of the medical professionals who have published guidelines on the subject. ${ }^{92} \mathrm{C}$ 's doctor could have performed an abortion on Irish soil if he felt it was medically necessary to save her life. $\mathrm{C}$ had a range of options to choose from after her primary care physician declined to deem the pregnancy a risk to her life.

Most importantly for C's claim, is the reality that the ECHR has held there is no corresponding "negative" right that goes along with the Article 2 right to life. In the framework of the euthanasia situation, the ECHR has stated that Article 2 does not encompass a negative right.

87. European Convention on Human Rights, supra note 15, art. 2.1 ("Everyone's right to life shall be protected by law. No one shall be deprived of his life intentionally save in the execution of a sentence of a court following his conviction of a crime for which this penalty is provided by law.").

88. Statement of Facts at Complaints, A., B. and C., App. No. 25579/05.

89. See Cyprus v. Turkey, 2001-IV Eur. Ct. H.R. 1, 58.

90. See Ocalan v. Turkey, 2005-IV Eur. Ct. H.R. 131, ๆ 156; Case of D. v. United Kingdom, 1997-III Eur. Ct. H.R. 777 (deciding the case under the Article 3 claim and not the Article 2 claim).

91. IR. CONST., 1937, art. 40.

92. See generally Medical Council, A Guide to Ethical Conduct and Behaviour (2004). "The Council recognizes the termination of pregnancy can occur when there is real and substantial risk to the life of the mother. ..." Id. § 24.6.

In current obstetrical practice rare complications can arise where therapeutic intervention is required at a stage in pregnancy when there will be little or no prospect for the survival of the baby, due to extreme immaturity. In these exceptional situations failure to intervene may result in the death of both mother and baby. We consider that there is a fundamental difference between abortion carried out with the intention of taking the life of the baby, for example for social reasons, and the unavoidable death of the baby resulting from essential treatment to protect the life of the mother.

Id. at app. C. 
The consistent emphasis in all the cases before the Court has been the obligation of the State to protect life. The Court is not persuaded that "the right to life" guaranteed in Article 2 can be interpreted as involving a negative aspect. While, for example in the context of Article 11 of the Convention, the freedom of association has been found to involve not only a right to join an association but a corresponding right not to be forced to join an association, the Court observes that the notion of a freedom implies some measure of choice as to its exercise [...]. Article 2 of the Convention is phrased in different terms. It is unconcerned with issues to do with the quality of living or what a person chooses to do with his or her life. To the extent that these aspects are recognised as so fundamental to the human condition that they require protection from State interference, they may be reflected in the rights guaranteed by other Articles of the Convention, or in other international human rights instruments. Article 2 cannot, without a distortion of language, be interpreted as conferring the diametrically opposite right, namely a right to die. ${ }^{93}$

Pursuing the argument of the Court respecting Article 2, it is clear that its language precludes the absurd result suggested by the petitioner. It would be inappropriate for the Court to minimize the protection Ireland affords the unborn. ${ }^{94}$ Especially considering that "Convention law does not impose rigid standards for requirements for Member States on moral questions. It sets certain minimal standards for the protection of fundamental human rights and gives a wide margin of discretion to States, depending on the nature of the right, on the nature of the issues and the importance of the issues at stake, and on the existence or absence of consensus or international law on the topic." 95 This is a case where the court should apply the margin of appreciation doctrine. Ireland's treatment of women in C's situation meets the minimal standard of protection under Article 2 and as such her claim should be denied.

\section{The Applicants Fail to Provide Evidence of the Discrimination Necessary for an Article 14 Claim}

Fourth, the women allege that Irish abortion law discriminates on the basis of sex and financial status (Article 14). ${ }^{96}$ The court wished to hear

93. Pretty v. United Kingdom, 2002-III Eur. Ct. H.R. 155, 186.

94. R.H. v. Norway, App. No. 17004/90, Eur. Comm'n H.R. Dec. \& Rep., http://cmiskp.ec hr.coe.int/tkp197/view.asp?item=1 \&portal=hbkm\&action=html\&highlight=17004/90\&sessionid $=60497281 \&$ skin $=$ hudoc-en (Court held that the Commission before its disbandment, held that the fetus enjoys a certain minimal level of protection of the unborn under Article 2 in certain circumstances).

95. Observations of Third Party Interveners at 5, A., B. and C., App. No. 25579/05.

96. European Convention on Human Rights, supra note 15, art. 14 ("The enjoyment of the of the rights and freedoms set forth in this Convention shall be secured without discrimination on any ground such as sex, race, colour, language, religion, political or other opinion, national or social origin, association with 
arguments on whether a discrimination claim could be made by a breach of Article 14 taken with Article 8, indicating that the Article 14 claim could not stand on its own. ${ }^{97}$ Thus, the women argue that the forced travel necessary to obtain an elective abortion or childbirth endangers pregnant women's lives, and that Ireland is discriminating against them because of their financial situation and sex.

To base their Article 8 claim on sex, the applicants would have to show that differential treatment by the State, of individuals in similar situations, did not have a reasonable and objective justification. ${ }^{98}$ Here however, all women are treated similarly by Ireland. Additionally, men and women are not similarly situated with regard to pregnancy and abortion restrictions, so it would be difficult to argue that the differential treatment did not have a reasonable and objective justification.

Along with the exceptions to the Article 8 claim, the ECHR also recognizes exceptions to Article 14 where they are necessary to protect a competing right. ${ }^{99}$ Here, Ireland is exercising its right as a State to protect life as a matter of public policy. ${ }^{100}$ Additionally, Article 14 only "complements the substantive provisions of the Convention. As access to abortion is not a right guaranteed by the Convention, Article 14 is not applicable." ${ }^{\prime 101}$ Even when combined with Article 8 claims, any discrimination claim fails. Ireland does have an exception which allows women to travel overseas to obtain an abortion if they choose to avail themselves of that opportunity. ${ }^{102}$ Ireland is not discriminating or interfering with bodily integrity when women who cannot afford to travel carry their pregnancies to term. ${ }^{103}$ Ireland has no positive duty to procure abortions for its citizens. As applied, the abortion prohibition "is both uniform and even-handed, applying to unborn children without reference

a national minority, property, birth or other status.”).

97. Statement of Facts at Questions to the Parties § 3, A., B. and C., App. No. 25579/05.

98. See Marckx v. Belgium, App. No. 6833/74, http://cmiskp.echr.coe.int/tkp197/view.asp?item= $2 \&$ portal=hbkm\&action $=\mathrm{html} \&$ highlight $=6833 / 74 \&$ sessionid $=60476701 \&$ skin=hudoc-en $(1979)$.

99. Observations of Third Party Interveners at 13, A., B. and C., App. No. 25579/05; cf. Case of East African Asians v. the United Kingdom, App. Nos. 4403/70-4419/70, 4422/70, 4423/70, 4434/70, 4443/70, 4476/70-4478/70, 4486/70, 4501/70 and 4526/70-4530/70, Eur. Ct. of H.R. (1973) (unpublished), http://cmiskp.echr.coe.int////kp197/viewhbkm.asp?action=open\&table=F69A27FD8FB86142BF01C11 66DEA398649\&key=1417\&sessionId=60487267\&skin=hudoc-en\&attachment=true.

100. European Convention on Human Rights, supra note 15, art. 2.

101. Observations of Third Party Interveners at 13, A., B. and C., App. No. 25579/05.

102. IR. CONST., 1937, art. 40.

103. European Convention on Human Rights, supra note 15, art. 14 (financial status is not expressly protected under Article 14). 
to any discrimination against women." ${ }^{104}$ The ECHR should find that a discrimination claim based on Article 14 falls short of meeting its burden of proof. Along with the failure of the applicants to meet their burden of proof on the discrimination claim, the ECHR typically affords the Council of Europe Member States a wide margin of appreciation regarding discrimination claims, making such deference appropriate here. ${ }^{105}$

After examining each of the claims, the alleged violations do not appear to rise to the level where the ECHR's intervention into Ireland's domestic sovereignty is necessary. Instead, Ireland seems justified under the European Convention on Human Rights in its policies banning abortion. The hardships caused by the ban are not disproportionate to the good Ireland views the ban as achieving.

III. The Absence of an International Right to Abortion and the Lack of Precedent for Imposing Such a Burden on Ireland and All Member States of the European Court of Human Rights Counsels Strongly Against the Creation of Such a Right

The ECHR would be overstepping its bounds by creating an international right to abortion for its Member States. Traditionally, the ECHR has found it inappropriate to impose its own moral view, especially one which is contrary to a particular moral view of a Member State, on the Member State. ${ }^{106}$ In other words, these types of issues fall into the margin of appreciation doctrine where the ECHR is to give deference to the Member State's determination of public policy on the issue. ${ }^{107}$ This has been particularly true when the court has faced issues about when to protect the right to life. For example in Vo v. France:

104. Observations of Third Party Interveners at 14, A., B. and C., App. No. 25579/05.

105. Lithgow and Others v. United Kingdom, App. Nos. 9006/80, 9262/81, 9263/81, 9265/81, 9266/81,9313/81,9405/1981, http://cmiskp.echr.coe.int/tkp197/view.asp?item=2\&portal=hbkm\&action= html\&highlight=Lithgow\&sessionid=60487924\&skin=hudoc-en (1986).

106. Observations of Third Party Interveners at 4, A., B. and C., App. No. 25579/05.

107. The basis of this doctrine is found in the Handyside v. United Kingdom, Eur. Ct. H.R. (1976), $\mathrm{http} / / / \mathrm{cmiskp}$. echr.coe.int/tkp 197/view.asp?item=1\&portal=hbkm\&action=html\&highlight=CaseofHan dysideTheUnitedKingdom\&sessionid $=60924649 \&$ skin=hudoc-en; see also R. St. J. MacDonald, The Margin of Appreciation, in The European System for the Protection of Human Rights 83 (MacDonald et al. eds., 1993); H.C. Yourow, The Margin of Appreciation Doctrine In the Dynamics of European Human Rights Jurisprudence (1996); The Doctrine of the Margin of Appreciation under the European Convention on Human Rights: Its Legitimacy in Theory and Application in Practice, 19 Hum. RTS. L.J. 1 (1998); Michael R. Hutchinson, The Margin of Appreciation Doctrine in the European Court of Human Rights, 48 INT'L \& CoMP. L.Q. 638, 638-50 (1999). 
[I]t is not only legally difficult to seek harmonization of national laws at the Community level, but because of the lack of consensus, it would be inappropriate to impose one exclusive moral code ... the issue of when the right to life begins comes within the margin of appreciation which the court generally considers that the States should enjoy in this sphere ... [and] the issue of such protection has not been resolved within the majority of the Contracting States themselves ... [and] there is no European consensus on the scientific and legal definition of the beginning of life. ${ }^{108}$

Similar to the ECHR's explanation about the inappropriateness of imposing abortion or another practice on all the Member states where there is no prevailing consensus, is Justice Scalia's concurrence in Planned Parenthood of Southeastern Pa. v. Casey.

The States may, if they wish, permit abortion on demand, but the Constitution does not require them to do so. The permissibility of abortion, and the limitations upon it, are to be resolved like most important questions in our democracy: by citizens trying to persuade one another and then voting. As the Court acknowledges, "where reasonable people disagree the government can adopt one position or the other." Ante, 505 U.S. at 851. The Court is correct in adding the qualification that this "assumes a state of affairs in which the choice does not intrude upon a protected liberty," ibid.- - but the crucial part of that qualification is the penultimate word. A State's choice between two positions on which reasonable people can disagree is constitutional even when (as is often the case) it intrudes upon a "liberty" in the absolute sense. Laws against bigamy, for example - with which entire societies of reasonable people disagree - intrude upon men and women's liberty to marry and live with one another. But bigamy happens not to be a liberty specially "protected" by the Constitution.

That is, quite simply, the issue in these cases: not whether the power of a woman to abort her unborn child is a "liberty" in the absolute sense; or even whether it is a liberty of great importance to many women. Of course it is both. The issue is whether it is a liberty protected by the Constitution of the United States. I am sure it is not. I reach that conclusion not because of anything so exalted as my views concerning the "concept of existence, of meaning, of the universe, and of the mystery of human life." Ibid. Rather, I reach it for the same reason I reach the conclusion that bigamy is not constitutionally protected-because of two simple facts: (1) the Constitution says absolutely nothing about it, and (2) the longstanding traditions of American society have permitted it to be legally proscribed. Akron II, supra, at 520. ${ }^{109}$

Here, Justice Scalia has aptly summarized one of this paper's main arguments. Reasonable minds differ over the beginning of life in the countries that comprise the Council of Europe. Once there is life, it is unquestionably

108. Vo v. France, App. No. 53924/00 at 37, http://cmiskp.echr.coe.int/tkp197/view.asp? item $=1 \&$ portal $=$ hbkm\&action $=\mathrm{html} \&$ highlight $=53924 / 00 \&$ sessionid $=60548338 \&$ skin $=$ hudoc-e $(2004)$; Observations of Third Party Interveners at 4, A., B. and C., App No. 25579/05.

109. 505 U.S. at 979-80 (1992) (Scalia, J., dissenting in part, concurring in part). 
protected by the European Convention of Human Rights. ${ }^{110}$ The right to life has primacy over all other rights. ${ }^{111}$ Ireland's definition of life is broader than some Member States and that provides more people with the right to life. Thus, analogizing Scalia's argument to the Grand Chamber of the ECHR's situation, the only reason the Grand Chamber should invade Ireland's domestic sovereignty is if Ireland's definition of life unreasonably intrudes into upon a "liberty" with stronger protection under the European Convention of Human Rights. Thus far in history, a right to abortion has never been recognized in either the Convention or the longstanding traditions of countries in the Council of Europe, which have long permitted abortion to be proscribed. This decision should be left to the Member States to sort out individually as a national matter, rather than in a single policy setting judicial pronouncement as the United States Supreme Court arguably did in Roe v. Wade. ${ }^{12}$

Recognizing that such a law indeed does place a burden on a woman living in Ireland who becomes pregnant, the Irish people also subsequently passed two additional constitutional amendments, the thirteent ${ }^{113}$ and fourteenth ${ }^{114}$ amendments. What the Irish Constitution strives to accomplish is an equitable balance between the respective rights of the unborn and the mother. The Irish formulation of that balance is something which the ECHR should respect in the absence of a countervailing recognized international right to abortion.

When courts look for grounds for an international right, they often look to custom or state practice, and international treaties and conventions. ${ }^{115}$ In cases such as these where the Member States have left the issue largely out of international treaties and conventions, custom and state practice can also inform treatment of the issue.

110. European Convention on Human Rights, supra note 15, art. 2.

111. Cf. Universal Declaration of Human Rights, supra note 42, preamble; International Covenant on Civil and Political Rights, supra note 42, art. 6.

112. See Roe v. Wade, 410 U.S. 113, 174 (1973) (Rehnquist, J., dissenting) (describing the Court's holding as a "sweeping invalidation of any restrictions on abortions").

113. IR. CONST., 1937, art. 40 ("This subsection shall not limit freedom to travel between the State and another state.").

114. Id. ("This subsection shall not limit freedom to obtain or make available, in the State, subject to such conditions as to be laid down by law, information relating to services lawfully available in another state.").

115. United Nations Statute of the International Court of Justice, art. 38, Apr. 18, 1946, 59 Stat. 1031. 


\section{A. Customary International Law and State Practice Do Not Provide Grounds for Creating an International Right to Abortion}

Customary international law is defined as "result[ing] from a general and consistent practice of states followed by them from a sense of legal obligation." ${ }^{116}$ Comment C to Section 102 of the Restatement further explains that, "[f]or a practice of states to become a rule of customary international law it must appear that the states follow the practice from a sense of legal obligation (opinio juris sive necessitatis); a practice that is generally followed but which states feel legally free to disregard does not contribute customary law. ${ }^{117}$ Brierly further elucidates the standards by stating that:

Custom in its legal sense means something more than mere habit or usage; it is a usage felt by those who follow it to be an obligatory one. There must be present a feeling that, if the usage is departed from, some form of sanction probably, or at any rate ought to, fall on the transgressor. ${ }^{118}$

A State may also avoid becoming bound by a customary international law if it consistently opposes the rule without interruption, becoming a persistent objector to the rule. ${ }^{119}$ At this point in time, there is no general or consistent state practice towards abortion. Individual States do not set their abortion policies based on a sense of legal obligation to any international customary law. By the Center for Reproductive Rights' (CPR) own admission, as of 2008, 68 countries worldwide prohibit abortion entirely or only allow it to save a mother's life. ${ }^{120}$ Additionally, 35 countries allow abortion only to preserve the physical health of the mother. ${ }^{121}$ Of the identified 196 world

116. Restatement (Third) of the Foreign Relations Law of the United States § 102(2) (1986); United Nations Statute of the International Court of Justice, supra note 115, art. 38 (stating that the court may use "international custom[] as evidence of a general practice accepted as law" in deciding cases).

117. Restatement (Third) of the Foreign Relations Law of the United States $§ 102 \mathrm{cmt}$. c (1987).

118. J.L. Brierly, The Law of Nations: An Introduction to the International Law of Peace 59 (6th ed. 1963).

119. David P. Fidler, Dinosaur, Dynamo, or Dangerous? Customary International Law in the Contemporary International System, in CONTEMPORARY PRACTICE OF INTERNATIONAL LAW 61, 66 (Ellen G. Schaffer \& Randall J. Snyder eds., 1997).

120. See The World's Abortion Laws, Center for Reproductive Rights, http:// reproductiverights.org/sites/crr.civicactions.net/files/pub_fac_abortionlaws2008.pdf.

121. Id. 
nations, only 56 nations allow abortion without restriction as to the reason. ${ }^{122}$ This falls short of establishing customary international law.

Despite the requirement for custom to be the consistent and general practice of states, courts often look to history and cite it as custom mandating a certain resolution of the issue. Although the presentation of the history in Roe would cause readers to believe that there had been no historical consensus on whether the unborn was life worthy or deserving of protection, the Roe opinion was selective in its historical presentation. ${ }^{123}$ The Grand Chamber faces pressure today to provide a "European solution" to the issue of abortion. The U.S. Supreme Court decided that since the status of the unborn life at conception could not be solved, it was better to err on the side of protecting the woman's right to privacy, created in Griswold v. Connecticut, and in one decision struck down all state statues criminalizing the performance and acquiring of an abortion procedure. ${ }^{124}$ This ruling left a complete void where any abortion procedure was permissible until state legislatures could pass new laws complying with the decision in Roe. ${ }^{125}$

Certainly, Justice Blackmun's presentation of the ancient history of abortion in Roe was not entirely untrue. ${ }^{126}$ Depending on how far back one examines history for custom or state practice to determine what the right to life meant and how the unborn were treated, there is irrefutable evidence that the right to life for the unborn, infants, and even adults was not always respected. Cultures were often quite inhumane toward the unborn and children. Yet the policies behind the denial of the right to life are now dissonant to the ear of the modern day emerging human rights culture. The practice and policies of these cultures are hardly supportable by the European Court of Human Rights. Because the ideologies behind the denial can no

122. $I d$.

123. Planned Parenthood of Se. Pa. v. Casey, 505 U.S. 833, 866 ("Where, in the performance of its judicial duties, the Court decides a case in such a way a to resolve the sort of intensely divisive controversy reflected in Roe ....."); Teresa Stanton Collett, Judicial Modesty and Abortion, 59 S.C.L. Rev. 701, 704-08 (2008) ("More than half of the majority opinion is devoted to a selective review of ancient and common law beliefs about abortion.").

124. 410 U.S. at $153-61$ (1973);

We need not resolve the difficult question of when life begins. When those trained in the respective disciplines of medicine, philosophy, and theology are unable to arrive at any consensus, the judiciary, at this point in the development of man's knowledge, is not in a position to speculate as to the answer. Id. at 159 .

125. Cf. Planned Parenthood of Se. Pa., 505 U.S. at 934 (Rehnquist, J., concurring in part, dissenting in part).

126. 410 U.S. at 130 (Blackmun, J.) (“Ancient religion did not bar abortion.”). 
longer be viewed as legitimate, the evidence that the practice occurred should not be used to support the Court's assumption of their role as moral arbiter where one is not needed, thus imposing a "right" to abortion upon Ireland.

Ancient Near Eastern cultures commonly practiced child sacrifice. For example, the Phoenician mothers placed babies, in the outstretched arms of the Baal idol above a fire where the babies were consumed by the flames as a sacrifice. ${ }^{127}$ The Canaanites sacrificed their children in fires to their god Molech. ${ }^{128}$ Ancient Egyptians killed their children, "disemboweling and dismembering them shortly after birth - their collagen was ritually harvested for the manufacture of cosmetic creams." "29 Some Polynesian cultures beat pregnant women's abdomens with large stones or heaped hot coals upon them. ${ }^{130}$ In these cultures, abortion or infanticide was not only allowed, but in some cases it was required or government mandated. It would be assumed that those who identify themselves as pro-choice would be hostile to any such government mandated abortions or judicial credence given to the ancient cultures permitting abortions as grounds for creating an international right to abortion.

While early western liberal tradition, founded in the Enlightenment period, highly regarded the ancient Greek society, the Classical world fails to provide a strong modern day argument for the creation of an international legalization of abortion. Indeed, "[t]he murder of new-born infants was a practice allowed in almost all of the states of Greece." 131 It can also fairly be alleged that the majority of the ancient Greeks permitted and promoted abortions. Plato himself sometimes permitted abortion, and indeed in his ideal society it would be required for women over the age of forty, although he recognized that the fetus was indeed a human being. ${ }^{132}$ The intellectual origins of the Chinese "one child policy" as a zero-population growth policy to avoid overcrowding can be found in Aristotle's Politics where he "required abortion before 'quickening,' whenever the number of state-permitted births became exceeded." ${ }^{\prime 133}$ The Classical support for abortion was decidedly in opposition

127. P. Hammond, The Abortion Holocaust, in Fight For Life 33 (M. Cain ed., 1995).

128. George Grant, Third Time Around: A History of the Pro-Life Movement from the First Century to the Present 12 (1991).

129. $I d$.

130. $I d$.

131. Michael J. Perry, Toward a Theory of Human Rights: Religion, Law, Courts 52 (2007)

132. Plato, The Republic 5.9, quoted in Michael J. Gorman, Abortion and the Early Church: Christian, Jewish \& Pagan Attitudes in the Greco-Roman World 21 (1982).

133. Aristotle, Politics 7:16, 13, 35, quoted in Francis Lee, Tiny Human Life 211 (2001), available at http://www.dr-fnlee.org/docs $2 /$ index.html (last visited Oct. 29, 2010). 
to the contemporary American notions of "privacy" as a space outside of governmental regulation. Both Aristotle and Plato espoused the philosophy that "the state's ideals and needs take precedence over the life and rights of the unborn" or infants and as such, the state could rightly determine the appropriate time to abort the life of the unborn. ${ }^{134}$ Plato and Aristotle's subsequent disregard of the lives of the unborn comes from their utilitarian belief of a human's purpose. In their eyes, each individual existed solely for the state, absolute rights did not exist, and even the right to life would be sacrificed if the best interests of the state demanded it. ${ }^{135}$ In general, most Europeans, even if they deny the unborn child's right to life, are solidly in favor of the absoluteness of their own right to life and thus would be disingenuous in relying on Plato or Aristotle's permission of abortion for support of the creation of a right to abortion. Certainly the Grand Chamber of the ECHR could not rely on the ancient custom to strike down Ireland's statute without simultaneously eliminating A, B, and C's individual right to life under Article 2.

The oft admired Pagan Roman Empire was no more sympathetic toward the unborn and even infants. Abortion was not usually regarded as being contrary to "Roman Moral Law" in Ancient Pagan Rome. ${ }^{136}$ The earliest Roman law code, the Twelve Tables, allowed a father to abandon to the elements any female infant or a deformed infant of either sex. ${ }^{137}$ Seneca, writing before 65 A.D., defended the drowning of deformed babies. ${ }^{138}$ In the Roman Republic, the father known as the Partria had the power of life and death over all inside his household, men, women, and children therefore any prohibitions against abortion derived from a view of it as an offense against the potential father. ${ }^{139}$ Surely A, B, and C could not allege a violation of their human rights with the above theory.

134. Gorman, supra note 132 , at 21.

135. Id. at 23 .

136. LEE, supra note 133, at 211.

137. H. Bennett, The Exposure of Infants in Ancient Rome, 18 ClassicAL J. 341, 342-43 (1922-23); Gorman, supra note 132, at 25; H. Tristram Engelhardt, JR., The Foundations of Bioethics 270 (2d. ed. 1996) ("Cicero remarks in his De Legibus, '[a] dreadfully deformed child ought to be killed quickly, as the Twelve Tables ordain' (De Legibus 3.8.19).”).

138. Seneca, Moral and Political Essays 32 (John M. Cooper \& J.F. Procope eds., Cambridge University Press 2003) (1995) (“[W]e destroy abnormal offspring at birth; children, too, if they are born weak or deformed, we drown. Yet this is not the work of anger, but of reason-to separate the sound from the worthless.").

139. Theodor Mommsen, Römisches Strafrecht 636 (1899); Gorman, supra note 132, at 25; cf. Cicero, Pro Cluentio, 11.32. 
What of the great Roman Empire? Motives for abortion varied during the Roman age, but many are shared by our own age. Some of the rich did not want to share their wealth with illegitimate children. ${ }^{140}$ Beautiful women practiced abortion to preserve their sex-appeal. ${ }^{141}$ The Roman poor felt unable to support many children. ${ }^{142}$ There is even a record of a woman aborting a baby after a divorce so she would not be reminded of the man she hated. ${ }^{143}$ Abortion was seen, much as it is today, as a corrective for failed contraceptives. ${ }^{144}$ The Roman Pagan writer Quintillian (A.D. 40-118) wrote, " $[\mathrm{t}$ ]o kill one's own children is sometimes considered a beautiful action, among the Romans." ${ }^{145}$ Even as late as 210 A.D., historians recorded many examples of feticide and infanticide occurring in the Roman Empire. ${ }^{146}$ King Herod the Idumaean ordered the deaths of all male children under the age of two in Bethlehem in an attempt to eliminate a perceived threat to his throne. ${ }^{147}$ Even as the Empire became more pro family under Octavian or Caesar Augustus, abortion was not forbidden because Roman law had borrowed from the Greek Stoics' view that the unborn was not human. ${ }^{148}$ Consequently following such a view, the laws against abortion which were in existence seem to have been mostly directed at punishing a woman for depriving her husband of children and for curbing a bad example of negating the maternal instinct. ${ }^{149}$ The Roman view of a human's purpose was similar to that of Plato and Aristotle, as one historian observes that, "even when born, the child was valued primarily not for itself but for its usefulness to the father, the family, and especially the state, as a citizen "born for the state." ${ }^{150}$ Laws remained lax against abortion until Constantine and the advent of the Christian Roman Empire.

140. Soranos, Gynecology 1:19, cited in Gorman, supra note 132, at 15.

141. Juvenal, Satire, 6.591-601, cited in Gorman, supra note 132, at 15.

142. Ambrose, Hexameron 5.18.58, cited in Gorman, supra note 132, at 15 .

143. Justinian, Digest 48.19.39, cited in Gorman, supra note 132, at 15.

144. Ephpanius, Panarion, cited in John A. Hardon, Euthanasia and Abortion: A Catholic View, 4 Hum. Life Rev. 88, 97-98 (1975).

145. LEE, supra note 133, at 271.

146. Hardon, supra note 144, at 96.

147. Matthew 1:18-2:18 (New King James); Flavius Josephus, The Works of Flavius Josephus, THE LEARNED AND Authentic Jewish Historian 403 (William Whiston trans., 1856) (“And since Herod had now the government of all Judea put into his hands, he promoted such of the private men of the city as had been of his party, but never left off avenging and punishing everyday those that had chosen to be of the party of his enemies.").

148. SeneCA, De Ira 1.15, quoted in Gorman, supra note 132, at 27.

149. Justinian, Digest 48.19.38.5.39, cited in Gorman, supra note 132, at 29-31.

150. Id. at 37.9.1.15, quoted in GoRmAN, supra note 132, at 32 . 
When considering the downright cruelty shown towards the unborn and infants in the Ancient world, one inescapable difference remains. Ireland, England, America, and most of the region addressed by the European Convention of Human Rights, as we understand the countries today, were not founded on Assyrian, Canaanite, or the utilitarian Greek and Roman worldviews but on Western, unmistakably Judeo-Christian, and Enlightenment premises. ${ }^{151}$ Men did not exist solely for the state; rather the state existed for men. The Declaration of Independence declared that man possesses absolute "unalienable" rights, the Bill of Rights plainly delineated some of them and, as in the European Convention on Human Rights, the right to life was one of the first mentioned. ${ }^{152}$ Hopefully, one would be laughed out of court if he or she attempted to legitimize a challenge to a statute forbidding infanticide on the grounds that the ancient Canaanite practice of burning their firstborn meant that the Council of Europe should not have a ban on the practice. One might assume that if the judges were going to base their decision on historical custom they should place more weight on the historical view that the Jews, Christians, Constantine's Roman Empire, and English Common Law recorder William Blackstone have taken on the importance and sanctity of human life.

Contrary to Justice Blackmun's presentation of the history in Roe, the judiciary was not always so disinclined or confused on how to define personhood. As early as 1795, an English court interpreted the ordinary meaning of the word 'children' in a will, to include a child still in the womb. ${ }^{153}$ Consistently, the court continued to declare, as in Thelluson $v$. Woodford, ${ }^{154}$ that unborn children, as such, are entitled to all the privileges of

151. See, e.g., Ir. ConST., 1937, pmbl. ("In the Name of the Most Holy Trinity, from Whom is all authority and to Whom, as our final end, all actions both of men and States must be referred, We, the people of Éire, Humbly acknowledging all our obligations to our Divine Lord, Jesus Christ, Who sustained our fathers through centuries of trial, Gratefully remembering their heroic and unremitting struggle to regain the rightful independence of our Nation, And seeking to promote the common good, with due observance of Prudence, Justice and Charity, so that the dignity and freedom of the individual may be assured, true social order attained, the unity of our country restored, and concord established with other nations, Do hereby adopt, enact, and give to ourselves this Constitution.”). For a selection of American Documents see "Historical Documents" located at http://www.wallbuilders.com/LIBissuesArticles.asp?cat=HD.

152. The Declaration of IndePendence (U.S. 1776); U.S. Const. amend. I.

153. Doe v. Clarke, (1795), 126 Eng. Rep. 617, 617; see Keeler v. Superior Court, 470 P.2d 617 (Cal. 1970) (holding that the homicide statute could not extend to the killing of a viable fetus); Following Keeler, Legislatures across the United States enacted Fetal Homicide Statutes. For a list of states with fetal homicide laws see the National Conference of State Legislatures article on Fetal Homicide Laws, available at http://www.ncsl.org/IssuesResearch/Health/FetalHomicideLaws/tabid/14386/Default.aspx (last visited Nov. 13, 2010).

154. Thelluson v. Woodford, (1799) 31 Eng. Rep. 117, quoted in LEE, supra note 133, at 272. 
other persons. William Blackstone's 1809 commentaries explain that not only do children have rights, but that parents have duties toward their offspring:

The duty of parents to provide for the maintenance of their children, is a principle of natural law; an obligation laid on them not only by nature herself, but by their own proper act, in bringing them into the world: for they would be in the highest manner injurious to their issue, if they only gave their children life, that they might afterwards see them perish. By begetting (conceiving) them therefore, they have entered into a voluntary obligation, to endeavour, so far as in them lies, that the life which they have bestowed shall be supported and preserved. And thus the children will have a perfect right of receiving maintenance from their parents. ${ }^{155}$

A critic might object, stating that this protection was in place in England before pregnancies were properly understood by science. However, the protection increased as science made advances.

As science made advances, laws in Ireland, England, and America kept pace with the discoveries. For example, "after the discovery of the human ovum in 1827, the British Parliament in 1837 enacted a new abortion statute effectively protecting unborn children even from the moment of conception." ${ }^{" 156}$ A New York Statute of 1829 made it a crime of manslaughter "for any abortionist who caused the death of a quickened child unless the reason was to preserve the life of the mother."157 These statutes indicate that the United States considered it necessary to keep abortion illegal and that they placed value on the unborn. In Ireland, providing or obtaining an abortion has been unlawful since the Offences Against the Person Act of $1861 .{ }^{158}$ Thomas F. Lambert Jr. ${ }^{159}$ wrote in 1968 an article titled, The Legal Rights of the Fetus, about the legal rights the fetus possessed from conception. In this regard, Lambert referred to the 1946 case, Bonbrest v. Kotz. ${ }^{160}$ There the district court held that "a child born alive and viable should be allowed to maintain an action in the courts for injuries wrongfully committed upon its person while

155. 1 William Blackstone, Commentaries *446-47 (emphasis added).

156. LEE, supra note 133, at 272.

157. Id.; de Freitas \& Finney, supra note 10, at 33-34.

158. Offenses Against the Person Act, 24 \& 25 Vict., c. 100, $\S 58-59$ (1861), available at http://www.bailii.org/uk/legis/num_act/1861/ukpga_18610100_en.pdf (stating that a woman who "[i]nten[ded] to procure her own Miscarriage ... [or] whosoever . . . shall unlawfully administer to her ... shall be guilty of Felony ..." and those who "supply or procure any Poison or other noxious Thing, or any Instrument ... knowing that the same is intended ... to procure the Miscarriage of any Woman ... shall be guilty of a Misdemeanor ....").

159. Editor in Chief of the American Trial Lawyers' Association, 1955-1972.

160. LeE, supra note 133, at 272; de Freitas \& Finney, supra note 10, at 33-34. 
in the womb of its mother." 161 The district court "persuasively reasoned that the unborn child was a separate biological (and hence legal) entity from the mother." ${ }^{162}$ In Sinkler v. Kneale, ${ }^{163}$ Justice Bok wrote that "[m]edical authorities have long recognized that a child was in existence from the moment of conception"-in existence as an individual human being distinct from his or her mother, "and not merely a part of its mother's body" until some unspecified time after conception." 164

As Justice Bok alluded to the medical field also provided historical grounds for opposing the legalization of abortion. The original Hippocratic Oath required doctors to swear: "I will not give to a woman a pessary to produce abortion." 165 It was not until the early nineteen-sixties that the Hippocratic Oath underwent a revision which removed the clause about abortion. ${ }^{166}$

At the time Roe was decided States had begun individually addressing and experimenting with various strengths of abortions statues. Change was occurring slowly. The benefits of federalism were being achieved by using the states as microcosms in which to experiment with varying approaches to the law. This is an opportunity that the Council of Europe Member States could still reap the benefit from and one which is compatible with the ECHR's margin of appreciation doctrine. ${ }^{167}$ Most of the states allow abortions in certain circumstances or with different restrictions, several like Ireland provide for it only in the case of protecting the life of the mother. ${ }^{168}$ Allowing

161. Bonbrest v. Kotz, 65 F. Supp. 138, 142 (D.D.C. 1948) (In that the case the injury was brain damage caused by an obstetrician.).

162. de Freitas \& Finney, supra note 10, at 33-34. See Bonbrest v. Kotz, 65 F. Supp. at 140-41; Timothy F. Lambert, Legal Rights of the Fetus, 1 The Christian LaWyer 23, 26 (1968).

163. 164 A.2d 93, 96 (Pa. 1960).

164. de Freitas \& Finney, supra note 10, at 34.

165. Hippocratic Oath, quoted in LeE, supra note 133, at 278; de Freitas \& Finney, supra note 10, at 34 .

166. See Dique, referenced in LeE, supra note 133, at 278. In 1948, the Declaration of Geneva was adopted by the General Assembly of the World Medical Organization, and began to be used in medical school graduation ceremonies. The new Declaration contained less of an adamant rejection of abortion stating simply: "I will maintain the utmost respect for human life-from the time of conception. Even under threat, I will not use my medical knowledge contrary to the laws of humanity." Id.

167. Handyside v. United Kingdom, App. No. 5493/72, Eur. Ct. H.R. $§ 49$ (1976), available at http://cmiskp.echr.coe.int/tkp197/view.asp?item=1\&portal=hbkm\&action=html\&highlight=Case|of|Han dyside|The|United|Kingdom\&sessionid=60924649\&skin=hudoc-en; Dudgeon v. United Kingdom, App. No. 7525/76, Eur. Ct. H.R. $\S 60$, available at $\mathrm{http}: / / \mathrm{cmiskp}$. echr.coe.int/tkp197/view.asp?item=2\&portal= $\mathrm{hbkm \& action}=\mathrm{html}$ \&highlight=Dudgeon|United $\mid$ Kingdom\&sessionid=61039962\&skin=hudoc-en (1981).

168. Observations of Third Party Interveners at 8, A., B. and C., App. No. 25579/05 ("In addition to Ireland, 68 countries worldwide prohibit abortion entirely or allow it only to save the mother's life. This includes Malta, Monaco, San Marino, and Andorra which are also signatories to the Convention."); see also 
these different approaches to be tried and tweaked will result in a better grasp on which policies are successful, and as the national governments understandably have more control over their own laws, they would prefer to be allowed the freedom to experiment.

\section{B. International Conventions/Treaties}

The next place to search for binding international law is in treaties or conventions. When the Universal Declaration of Human Rights (UDHR), the United Nations Convention on the Rights of the Child (UNCRC), the International Covenant on Civil and Political Rights (ICCPR), the International Covenant on Economic, Social and Cultural Rights (ICESR), and Convention on the Elimination of All Forms of Discrimination against Women (CEDAW) are examined, one of the things they have in common is that none have been interpreted to encompass a right to abortion. Indeed, language in a few of the above documents could be interpreted to hold that the unborn are protected. ${ }^{169}$ Even attorneys for the Center for Reproductive Rights arguing

Polish Abortion Case, Constitutional Court of Poland, OTK Z.U. z.r. 1997, Nr. 2, 19; MediCal Council, A Guide to Ethical Conduct and Behaviour, Appx. (2004) ("In current obstetrical practice rare complications can arise where therapeutic intervention is required at a stage in pregnancy when there will be little or no prospect for the survival of the baby, due to extreme immaturity. In these exceptional situations failure to intervene may result in the death of both mother and baby. We consider that there is a fundamental difference between abortion carried out with the intention of taking the life of the baby, for example for social reasons, and the unavoidable death of the baby resulting from essential treatment to protect the life of the mother."); Institute of Obstetricians and Gynaecologists, Written Submission of the Institute of Obstetricians and Gynaecologists to the All-Party Oireachtas Committee on the Constitution, as contained in its Fifth Progress Report, app. IV, at A407.

169. See Universal Declaration of Human Rights, supra note 42, at pmbl. ("Whereas recognition of the inherent dignity and of the equal and inalienable rights of all members of the human family is the foundation of freedom, justice and peace in the world . . .."); Vo v. France, App. No. 53924/00 § 24.1, http://cmiskp.echr.coe.int/tkp197/view.asp?item=1\&portal=hbkm\&action=html\&highlight=53924/00\& sessionid=60548338\&skin=hudoc-e (2004) (holding by the ECHR "that the embryo/foetus belongs to the human race."); see, e.g., Observations of Third Party Interveners at 3, A., B. and C., App. No. 25579/05 ("The right to protection of the unborn is also a fundamental component of the United Nations Convention on the Rights of the Child (UNCRC) to which Ireland is a signatory. Under the UNCRC, the child has the right to life, Parties are obliged to ensure their survival 'to the maximum extent possible,' and the child deserves special care and legal protection 'before as well as after birth."'); United Nations Convention on the Rights of the Child, supra note 42, at pmbl., arts. 3, 6; International Covenant on Civil and Political Rights, supra note 42 (protecting pregnant women from capital punishment by Article 6 of the International Covenant on Civil and Political Rights which serves to preserve the unborn child's life.); Observations of Third Party Interveners at 3, A., B. and C., App. No. 25579/05 ("The Commission on European Human Rights determined that the fetus has the benefit of certain protection under the first sentence of Article 2 of the European Convention of Human Rights.”); R.H. v. Norway, App. No. 17004/90, Eur. Ct. of H.R. (May 19, 1990), http://cmiskp.echr.coe.int/tkp197/view.asp?item=1\&portal=hbkm\&action=html\&highlight 
vigorously that access to abortion is a human right, admit that the right cannot be found in binding treaty law with a single regional exception. ${ }^{170}$

The first rule of treaty interpretation is found in the Vienna Convention on the Law of Treaties, which states, "[a] treaty shall be interpreted in good faith in accordance with the ordinary meaning to be given to the terms of the treaty in their context and in the light of its object and purpose." ${ }^{171}$ The word abortion cannot be found in any global United Nation's treaty. ${ }^{172}$ Nor can a right to abortion be inferred from the ordinary meaning given to any global United Nation's treaty in light of the treaties object and purpose. For example, when looking at the context around the drafting of such documents as the UDHR, ICCPR, CEDAW, and the UNCRC, one notices that many of the drafting and signatory countries had laws forbidding abortion. There is no indication that the countries intended to alter their domestic laws on the subject by ratifying the above treaties, as they have for the most part kept their laws protecting unborn life or criminalizing abortion unaffected. Besides the context, when reading the plain language of the treaties, it is often easier to reconcile the language of the documents with protections for the unborn than the creation of a right to abortion. As an illustration, the UNCRC, which has been ratified by every country but the United States and Somalia, defines a child in Article 1 as "every human being below the age of eighteen." 173 This importantly declares nothing about the minimum age of the child, simply defining the maximum age. Article 6 guarantees all children under the UNCRC "the inherent right to life" and impose on States a responsibility to ensure "the survival and development of the child." ${ }^{174}$ Although a preamble is not binding law, the Vienna Convention allows preambles to constitute part of the context in determining the meaning of provisions, and the preamble to

$=17004 / 90 \&$ sessionid $=60497281 \&$ skin $=$ hudoc-en.

170. Christina Zampas \& Jamie M. Gher, Abortion as a Human Right-International and Regional Standards, 8 Hum. RTs. L. Rev. 249, 252 (2008); The African Union Convention on Protocol to the African Charter on Human and People's Rights on the Rights of Women in Africa known as the Maputo Protocol, is "the only legally binding human rights instrument that explicitly addresses abortion as a human right." Id. at 250 .

171. Vienna Convention on the Law of Treaties, art. 31, May 23, 1969, 1155 U.N.T.S. 331.

172. It is interesting to note that the one regional treaty that mentions "medical abortion" the African Union Convention on the Protocol to the African Charter on Human and People's Rights on the Rights of Women in Africa has not been ratified by half of the countries which signed it. http://www.africaunion.org/root/au/Documents/Treaties/List/Protocol\%20on\%20the\%20Rights\%20of\%20Women.pdf.

173. UNCRC, supra note 169, art. 1; For more information on the Convention of the Rights of the Child see Frequently Asked Questions on the Convention on the Rights of the Child on the UNICEF website, http://www.unicef.org/crc/index_30229.html (last accessed Sept. 25, 2010).

174. UNCRC, supra note 169, art. 6. 
the UNCRC recognizes a child as needing legal protection, "before as well as after birth." ${ }^{175}$

Abortion advocates have attempted, without success, to get a right to abortion incorporated to some of the above mentioned treaties. Specifically there was debate about the issue at the 1994 International Conference on Population and Development in Cairo and at the 1995 World Conference on Women. The effort failed, and neither the Cairo Programme of Action nor the Beijing Platform of Action of 1995 produced from those conferences contains a right to abortion. These documents are not binding in international law, but it is telling that the strongest statement pro-choice advocates were able to wrangle from the conferences was that "where abortion is not against the law, such abortion should be safe." 176 The Cairo Programme of Action and the Beijing Platform of Action also lend credence to the margin of appreciation of the ECHR when they state, "any measures or changes related to abortion within the health system can only be determined at the national or local level according to the national legislative process. ${ }^{177}$ Mary Ann Glendon, the Learned Hand Professor of Law at Harvard, found it striking that the Programme of Action rather than treating abortion as a right, asked governments to seek to "reduce the recourse to abortion," "eliminate the need for abortion" and strive to "avoid repeat abortions." ${ }^{178}$ In contrast to this treatment of abortion she observes, "[o]ne would hardly say of an important right like free speech, for example, that governments should reduce it, eliminate the need for it, and help avoid its repetition." 179 The ECHR would have to fashion the right out of whole cloth.

IV. Ireland's Personal Historic Commitment to Protection of the Unborn and Its Reservation to the Lisbon Treaty to Ensure That Its Policy Would Continue as Ireland Functioned as a Member of the European Community Indicates That This Issue Should Be Left to the Margin of Appreciation Doctrine

Ireland has long demonstrated a strong, consistent, persistent commitment

175. Vienna Convention, supra note 171, art. 31; UNCRC, supra note 169, pmbl.

176. See Report of the International Conference on Population and Development, supra note 61, at $\S 8.25$.

177. Id. § 8.25; Fourth World Conference on Women, Sept. 4-15, 1995, Beijing Declaration and Platform for Action, 106(k), U.N. Doc. A/CONF.177/20.

178. See Report of the International Conference on Population and Development, supra note 61, at $\S 8.25$.

179. Mary Ann Glendon, What Happened at Beijing, 59 First Things 30, 30 (1996). 
to the protection of the unborn and while protecting the unborn maintains the lowest maternal mortality rate of all Europe. ${ }^{180}$ When in the wake of World War II, Ireland signed the Treaty of London, creating the Council of Europe on May 9, 1949, Ireland could not have envisioned membership in such Council calling into question the legitimacy of Ireland's protection of the unborn. ${ }^{181}$ In the intervening time period between the creation of the Council of Europe and the advent of the European Union, some countries began to liberalize abortion restrictions. As is recited earlier in this article, Ireland's response to this new dynamic was to pass their constitutional amendment protecting unborn life. ${ }^{182}$ Ireland has remained committed to the protection of the unborn. Ireland's moral view on the prohibition of abortion is so fervent that when Ireland ratified the Treaty on the European Union in 1992, voters had to have a protocol explicitly protecting Ireland's constitutional amendment. ${ }^{183}$ Ireland maintained their commitment to protecting unborn life when they made sure that the same protocol applied to the new treaty obligations created in the Treaty of Lisbon. ${ }^{184}$

180. See supra note 66 for a discussion of Ireland's consistent and persistent commitment to protecting the unborn; for information on the low mortality rate see http://www.irishhealth.com/ index.html?level=4\&id=13789 and Reardon et al., supra note 62 , at 279 , available at http:// www.afterabortion.org/research/DeathsAssocWithAbortionJCHLP.pdf.

181. Treaty of London, Statute of Council of Europe, May 5, 1949, C.E.T.S 001. At the time, countries were concerned with making sure horrible violations of human rights never occurred again, and international documents were being drafted which would expand protections of these human rights. Few if any countries permitted abortion. See Lawrence H. Tribe, Abortion: The Clash of Absolutes 58 (1992) (Abortion had been legalized in Russia in 1920 under Lenin, but Stalin outlawed it again in 1936.); Nazi Germany permitted abortions during the 1930's -40 's and sterilization for those deemed "hereditarily ill" while Aryan women were specifically prohibited from obtaining abortions. Id. at 59. Mexico legalized abortion in the case of rape in 1931. Kristen Olsen, Chronology of WoMen's History 232 (1994). On July 11, 1932 Poland legalized abortion in cases of rape and threats to maternal health, ABORTION Policies: A Global Review Volume III Oman to Zimbabwe 38 (United Nations 2002). In 1938, Sweden legalized abortion on a limited basis in Sweden. Id. at 115. On January 28, 1935 Iceland became the first Western country to legalize therapeutic abortion under limited circumstances. ABORTIONS: WEBSTER's Quotations, Facts, AND Phrases 102 (ICON Group International, Inc. 2008). In 1948 the Eugenic Protection Act in Japan expanded the circumstances in which abortion was allowed. ABORTION POLICIES: A Global Review Volume II Gabon to Norway 79 (United Nations 2001).

182. IR. CONST., 1937, art. 40.

183. Treaty on European Union (Treaty on Maastricht), Feb. 7, 1992, 1992 O.J. (C 191) 1, available $a t$ http://eur-lex.europa.eu/en/treaties/dat/11992M/tif/JOC_1992_191_1_EN_0001.pdf(“Nothing in the Treaty on European Union, or in the Treaties establishing the European Communities, or in the Treaties or Acts modifying or supplementing those Treaties, shall affect the application in Ireland of Article 40.3.3. of the Constitution of Ireland.").

184. See Millward Brown Ims, Post Lisbon Treaty Referendum Research Findings ii, iii (2008), available at http://www.dfa.ie/uploads/documents/Publications/Post $\% 20$ Lisbon\%20Treaty\% 20Referendum $\% 20$ Research $\% 20$ Findings/post $\% 20$ lisbon $\% 20$ treaty $\% 20$ referendum $\% 20$ research $\% 20$ fin dings_sept08.pdf; see also Dep't of Foreign Affairs [Ir.], white paper: An Explanation of Changes to the 
Nothing in the Treaty of Lisbon attributing legal status to the Charter of Fundamental Rights of the European Union, or in the provisions of that Treaty in the area of Freedom, Security and Justice affects in any way the scope and applicability of the protection of the right to life in Article 40.3.1, 40.3.2 and 40.3.3, the protection of the family in Article 41 and the protection of the rights in respect of education in Articles 42 and 44.2.4 and 44.2.5 provided by the Constitution of Ireland. ${ }^{185}$

The Treaty of Lisbon addresses the European Union and not the Council of Europe and as such, has no legal force in limiting the ECHR's jurisdiction over Ireland on the abortion issue. However, it still illustrates the value that Ireland places on unborn life. It would seem ironic if a treaty Ireland signed 51 years ago, never expecting it to create a limitation on a fundamental human right, would now tell Ireland it must obey by the Grand Chamber's ruling and use Ireland to create precedent for an international right to abortion, when Ireland has so clearly made its views on the subject known with its reservation to the Treaty of Lisbon. This would seem to be an area where the ECHR could conclude that Ireland's constitutional amendment reflects the principle that Ireland has chosen to extend a higher level of protection of human rights in its national legislation than is required to by the European Convention on Human Rights and thus the ECHR should give Ireland's policy determination deference according to the margin of appreciation doctrine. ${ }^{186}$

\section{Procedural Barriers to Accepting the Case}

Notwithstanding all the ways the case fails on the merits, procedurally speaking it never should have ended up before the ECHR. The European Convention on Human Rights clearly specifies that applicants should look first to their own domestic courts for remedies before applying to the ECHR. The admissibility criteria for cases are set forth in Article 35 of the Convention. ${ }^{187}$

Functioning of the European Union made by the Lisbon Treaty 35 (2009), available at http://www.dfa.ie/uploads/documents/EU\%20Division/EU\%20Reform\%20Treaty/white\%20paper\%20\%20final\%20-\%20low\%20res\%20from\%20printers\%20-\%20020709.pdf.

185. Decision of the Heads of State of Government of the 27 Member States of the EU, Meeting Within the European Council, on the Concerns of the Irish People on the Treaty of LisBon, Treaty of Lisbon, Annex 1, Nov. 25, 2009, at 1.

186. European Convention on Human Rights, supra note 15, art. 53 (Parties to the Convention are free and encouraged to provide a higher level of protection of human rights in their own national legislation.).

187. Id. art. 35 ("The Court may only deal with the matter after all domestic remedies have been exhausted, according to the generally recognised rules of international law, and within a period of six months from the date on which the final decision was taken."). 
Based on Article 35.1, A, B and C should have begun the procedure in the Irish court system. Neither A, B nor C filed a single piece of paper with an Irish court about their claims. According to Article 35.4, the applicants remain in danger of having their case thrown out at any point before a judgment is handed down, even after the hearing has taken place. ${ }^{188}$ Indeed, the Grand Chamber recognizes the procedural defect in the first question it asked the parties to prepare for oral arguments inquiring, "Have the applicants exhausted domestic remedies as required by Article 35 of the Convention?"189

This is not the first time the Court has been faced with examining Ireland's constitutional amendment protecting unborn life. In a 2006 admissibility decision, the ECHR held that the most important way to assert and vindicate constitutional rights would be in the Irish judicial system. ${ }^{190}$ They have made similar decisions in other cases alleging similar violations of Irish constitutional rights. ${ }^{191}$ Essentially, the applicants must have exhausted their domestic remedies to the Court's satisfaction before the Grand Chamber will look any further into the substantive portion of the case.

Applicants should not be confused on what would qualify as an exhaustion of domestic remedies in the Irish Court system. In denying the application for D. v. Ireland, the European Court of Human Rights ruled that "a declaratory action before the Member State's High Court, with a possibility of an appeal to the Supreme Court, constitutes the most appropriate method under Irish Law of seeking" relief. ${ }^{192}$

The Irish court has looked at cases which attempt to appropriately balance the right of the unborn child to life with the right of the mother to her own bodily integrity. ${ }^{193}$ The Irish courts have repeatedly held that no single interpretation of the constitution is meant to be final for all time, and therefore A, B, and C's chances of succeeding on their claim would not be precluded by prior precedent. ${ }^{194}$ Indeed, in the Att' $y$ Gen. $v$. $X$ case where the Irish court was

188. Id. ("The Court shall reject any application which it considers inadmissible under this Article. It may do so at any stage of the proceedings.").

189. Statement of Facts at Questions to the Parties, § 1, A., B. and C., App. No. 25579/05.

190. D. v. Ireland, App. No. 26499/02, § 85 (2006), http://www.echr.coe.int.

191. Holland v. Ireland, App. No. 24827/94, 93-A Eur. Comm'n H.R. Dec. \& Rep. 15 (1998); Indep. News and Media and Indep. Newspapers (Ireland) Ltd. v. Ireland, App. No. 55120/00 (2003), http://cmiskp.echr.coe.int/tkp197/view.asp?item=1\&portal=hbkm\&action=html\&highlight=55120\&ses sionid $=61044462 \&$ skin $=$ hudoc-en; $c f$. Observations of Third Party Interveners at 1, A., B. and C., App. No. $25579 / 05$

192. D. v. Ireland, App. No. 26499/02, § 85 (2006), http://www.echr.coe.int; $c f$. Observations of Third Party Interveners at $1, A$., B. and C., App. No. 25579/05.

193. Att'y Gen. v. X. and Others, [1992] 1 I.R. 1 (Ir.).

194. Id. ("Walsh J., stated as follows at pp. 318-19 of the report:- . . . According to the preamble, 
presented with a fourteen-year-old rape victim, the justice noted that using those type of interpreting principles were "peculiarly appropriate and illuminating in the interpretation of a sub-section of the constitution which deals with the intimate human problem of the right of the unborn to life and its relationship to the right of the mother of an unborn child to her life." 195 However, A, B, and C did not submit their cases individually or collectively to any court in the Irish legal system. They did not give the Irish judicial system the chance to offer an adequate resolution of the issues. They also did not create a record for the ECHR to review.

Of course the European Convention also provides protections for citizens who can show exceptional circumstances that would justify the immediate filing of an application directly to the ECHR. The burden for using this procedural absolution has historically been very high. A, B, and C allege that they would not be successful in a domestic remedy even with the ability to protect their identities with in camera proceedings. ${ }^{196}$ Again, the Court has continually held "that legal advice as to the possibility of success before national courts does not constitute a valid excuse for not exhausting a particular remedy." 197 Taking the Statement of Facts in the case seriously, it is also clear that the tension between the women's rights and the unborn's rights are being examined and dealt with on a fairly regularly basis internally in Ireland. ${ }^{198}$ This constant reexamination by the courts, legislatures, and

the people gave themselves the Constitution to promote the common good, with due observance of prudence, justice and charity so that the dignity and freedom of the individual might be assured. The judges must, therefore, as best they can from their training and their experience interpret these rights in accordance with their ideas of prudence, justice and charity. It is but natural that from time to time the prevailing ideas of these virtues may be conditioned by the passage of time; no interpretation of the Constitution is intended to be final for all time. It is given in the light of prevailing ideas and concepts" (quoting McGee v. Att'y Gen., [1971] 1 I.R. 284 (Ir.))); Observations of Third Party Interveners at 1, A., B. and C., App. No. $25579 / 05$.

195. Att'y Gen. v. X. and Others, [1992] 1 I.R. 1 (Ir.); cf. Observations of Third Party Interveners at 1, A., B. and C., App. No. 25579/05.

196. Applicant's Reply to the Observations of Ireland on the Admissibility and Merits, at $\S \S 58-63$, A., B. and C. v. Ireland, App. No. 25579/5 (Eur. Ct. H.R. Dec. 23, 2008). A similar argument was made by the applicant and lost in D. v. Ireland, App. No. 26499/02 (2006), http://www.echr.coe.int.

197. Cf. X v. Belgium, App. No. 1488/62, 13 Collection of Decisions 93, 96; Observations of Third Party Interveners at 2, A., B. and C., App. No. 25579/05.

198. Statement of Facts at The Facts, $\S(B)(5), A$., B. and C., App. No. 25579/05 (stating that the Constitutional Review Group issued a report in 1996 considering amending Article 40.3.3 to allow abortion in certain limited Constitutionally defined circumstances); The interdepartmental Working Group Green Paper on Abortion from September 1999 was submitted by the government to a committee on the Constitution which proposed possible options for the resolution of the dissatisfaction of both prolife and prochoice factions within Ireland. Id. § 6. In 2000, a Fifth progress report was released which agreed to create an agency that would help to provide contraceptive services, offer services which would decrease the 
indeed by the people through proposed referendums to the constitution presents the applicants plenty of domestic options to vindicate their claimed rights and to persuade Ireland to consider their opinions.

In deeming the application admissible and holding a hearing in $A$., B. and $C$. v. Ireland, the Court has taken a step towards allowing the marginalization of all of its Member States domestic courts. This lowering of the standard typically applied to Article 35 should cause Member States of the Council of Europe to consider how dearly they hold onto their domestic sovereignty. ${ }^{199}$ For indeed, such a blow to the relevance of each State's respective domestic legal system is an attack, or at least diminution, of one of the founding principles of International Law: domestic sovereignty. ${ }^{200}$ Procedurally speaking, if the court wished to avoid judicial activism it should have turned away A, B, and C's application until after they had litigated their claims through the Irish Court System. ${ }^{201}$

desire for abortions, and providing post abortion counseling and medical checkups for women who do choose to travel abroad to obtain an abortion. Id. § 6. Finally, in 2002, a proposed amendment to the Constitution attempted to legalize abortions inside Ireland if they were conducted at specific facilities when necessary to prevent a risk of loss of the women's life, but the risk was not suicide. The proposal was narrowly defeated by a margin of $50.42 \%$ to $49.58 \%$ in favor. Id. $\S 8$. For the ECHR to impose abortion on a country who is close to deciding that in certain circumstances abortions may be medically necessary seems to do it a profound disservice. The country is painstakingly considering the rights of all its citizens not denying them any chance of relief. An imposition from an outside source could result in a violent backlash of regulations and protests which would upset this delicate balance.

199. Observations of Third Party Interveners at 2, A., B. and C., App. No. 25579/05.

200. It is true that each Member State of the European Union has voluntarily chosen to relinquish a portion of their domestic sovereignty. Many as Ireland did expressed specific reservations to the Treaty of Lisbon which dictated what was outside the reach of the European Union, despite the Member States receipt of the benefits of the European Union. For the ECHR to expand beyond its mandate, which requires the cases to go through the domestic court systems, would be taking a piece of domestic sovereignty away from the Member States that they had not [page break] contracted away; see Observations of Third Party Interveners at 3, A., B. and C., App. No. 25579/05 ("[t] he Principle of respect for National Sovereignty, and not the erosion thereof, forms the basis for Convention rights themselves, because those rights stemmed from the treaty obligations undertaken by the High Contracting parties. For any organ of the Council of Europe to hold that Ireland's laws protecting life must be liberalised would create a new Convention right to which Ireland never acceded, and would place obligations on Ireland to which it never became a party.").

201. It is possible that Grand Chamber retained the case despite its procedural defect, due to another sovereign nation, Lithuania, intervening in the case. Lithuania filed a brief requesting clarification on a Council of Europe Resolution regarding abortion. Observations, submitted by the Government of the Republic of Lithuania, A., B. \& C. v. Ireland, App. No. 25579/05 (E.C.H.R. Nov. 14, 2008). There is some confusion over whether the Lithuanian official who submitted the brief was correctly authorized by the Lithuania government to do so, since Lithuania opposed and voted against the resolution. There is speculation that the brief may be withdrawn by the Lithuanian Government and at this time the Lithuanian Conference of Catholic Bishops is negotiating unofficially with the Lithuanian Government. See Audre Srebaliene, Po aborto lietuve kovoja Strasbure, LRYTAS.LT, Sept. 29, 2010, at http://m.lrytas.lt/?data= 20100929\&id=akt29_a4100929\&view=2. 


\section{Lessons Learned: The American Experience/Experiment}

Even when dealing with abortion on an international level, it is appropriate to also examine the United States situation, as its judges have often been on the forefront of the legal issue. Also, American jurisprudence on the unborn has been infectious, influencing the course of abortion jurisprudence in a number of other countries. ${ }^{202}$

Professor Noonan ${ }^{203}$ succinctly summarized the American situation in 1982: "By virtue of [the U.S. Supreme Court's] opinions, human life has less protection in the United States than any country of the Western World." ${ }^{204}$ Because of the combination of two decisions handed down together in 1973 (Roe v. Wade ${ }^{205}$ and Doe v. Bolton ${ }^{206}$ ), the United States Senate Judiciary Committee concluded that, "no significant legal barriers of any kind whatsoever exist today in the United States for a woman to obtain an abortion for any reason during any stage of her pregnancy."207 The Justices have decided that it is up to every individual to decide whether the unborn deserves a chance at life because, "[a]t the heart of liberty is the right to define one's own concept of existence, of meaning, of the universe, and of the mystery of human life. Beliefs about these matters could not define the attributes of personhood were they formed under compulsion of the State. ${ }^{208}$ Since 1973, Americans struggling to define the mystery of human life have remained deeply divided on the issue. ${ }^{209}$ Despite the Court's sanction of the woman's right to choose, numerous battles continue to rage in the courts over the issue or the implementation of the right. ${ }^{210}$ Thus, 37 years after the decision in Roe,

202. Reed Boland, Recent Developments in Abortion Law in Industrialized Countries, 18 Law, MeD. And Health Care 404, 404-18 (1990).

203. Professor of Law at the University of California (Berkeley).

204. J.T. Noonan, Why a Constitutional Amendment?, 1 Hum. Life Rev. 26, 28 (1975), quoted in Francis Schaeffer, 5 The Complete Works of Francis Schaeffer 294-95 (1982).

205. See Roe v. Wade, 410 U.S. 113 (1973).

206. See Doe v. Bolton, 410 U.S. 179 (1973).

207. S. ReP. No. $98-149$, at 6 (1983).

208. Planned Parenthood of Se. Pa. v. Casey, 505 U.S. 833, 851 (1992).

209. See Gallup Polls (May 7-10, 2009), http://www.gallup.com/poll/1576/abortion.aspx, http://www.gallup.com/poll/1 18399/More-Americans-Pro-Life-Than-Pro-Choice-First-Time.aspx (placing the national split at $51 \%$ of Americans identifying as pro-life and $42 \%$ of Americans identifying as prochoice); see also The Pew Forum on Religion \& Public Life (Oct. 1, 2009), http://pewforum.org/ Abortion/Support-for-Abortion-Slips.aspx (verifying similar results in a national survey PEW Research Center).

210. Parental Consent, Spousal Notification, Conscientious Objectors, Partial Birth-Abortion, whether abortion should be funded by Medicare, whether the Universal Health Care Bill should cover 
unlike what Justice Sandra Day O'Connor tried to accomplish in Planned Parenthood of Southeastern Pa. v. Casey, the Supreme Court's decision did not settle or put an end to the controversy. ${ }^{211}$ It is equally unlikely that the forcible implementation of an international right to abortion in Europe would quickly solve the problems the women in $A$., B. and C. v. Ireland are worried about.

\section{Conclusion: Restraint! The Court Should Respect Ireland's Domestic Sovereignty and Refrain from Fashioning a Fundamental Right to Abortion of Its Own Initiative}

The Court faces an important choice with this case. It would be breaking new ground if it made the decision to overrule Ireland's constitutional amendment and intrude into Ireland's domestic realm. One of the consulting attorneys in the case even predicts that another ${ }^{212}$ perceived activist decision "could be the demise of the ECHR," and could cause the Member States to lose confidence in the Court. ${ }^{213}$ The attack on Ireland's domestic sovereignty could be perceived as an attack on all Members States' ability to control their own affairs which could have repercussions for the functioning of the European Union.

Ireland's definition of life expands protection for those genetically human. As this is an expansion in keeping with the move toward universal

\footnotetext{
abortion, etc. Harris v. McRae, 448 U.S. 297 (1980) (determining the Constitutionality of the Hyde Amendment); Alpha Med. Clinic v. Anderson, 128 P.3d 364, 373 (Kan. 2006) (prosecuting Planned Parenthood for failure to report suspected child sex abuse even though they are a mandatory reporter); Tucson Women's Clinic v. Eden, 371 F.3d 1173 (9th Cir. 2004) (discussing abortion clinic regulations); Cenzon-Decarlo v. Mount Sinai Hosp., No. 09 CV 3120 (E.D.N.Y. Jan. 15, 2010) (discussing a NY nurse forced to assist in an abortion); Planned Parenthood of Minn. v. Rounds, 530 F.3d 724 (8th Cir. 2008) case challenging an informed consent statute).

211. Planned Parenthood of Se. Pa., 450 U.S. at 867 ("Where, in the performance of its judicial duties, the Court decides a case in such a way as to resolve the sort of intensely divisive controversy reflected in Roe and those rare, comparable cases, its decision has a dimension that the resolution of the normal case does not carry. It is the dimension present whenever the Court's interpretation of the Constitution calls the contending sides of a national controversy to end their national division by accepting a common mandate rooted in the Constitution.").

212. Lautsi v. Italy, App. No. 30814/06 (2009) (holding that Italian public schools could not display crucifixes in the classroom) (referred to the Grand Chamber, heard March 1, 2010); Sahin v. Turkey, App. No. 44774/98, § 16 (2005) (holding by the Grand Chamber that Turkey was allowed to ban Islamic headscarves in public schools). The decisions caused much unrest and several protests.

213. William Saunders, A.B.C. v. Ireland, The Catholic Thing (Dec. 15, 2009), http:// www.thecatholicthing.org/columns/2009/abc-v-ireland.html (William Saunders is a graduate of Harvard Law School and Senior Vice President of Legal Affairs at Americans United for Life).
} 
human rights, etc. rather than a limitation or deprivation of rights, the Grand Chamber should uphold Ireland's constitutional amendment protecting unborn life. The hardships the women face do not rise to a level which violates their basic Human Rights under the European Convention on Human Rights. However, the ECHR does not even need to rule on the merits of any of the violations of the European Convention on Human Rights claims, but could choose to dismiss the case due to the case's blatant procedural defects. Creating an international right to abortion for the European Continent would be an overreaching act of judicial activism that would limit the restrictions countries could put on abortions and invalidate many laws already in existence, and would have limited expansion of the rights the ECHR was created to protect. ${ }^{214}$ The ECHR should use restraint and allow Ireland to exercise its own domestic power as it considers the issue, rather than choosing to intervene with Ireland's domestic policy and overturn a constitutional amendment put in place by referendum in 1983, forever irrevocably altering Ireland's prolife policies, and simultaneously creating precedent for an international right to abortion for all Council of Europe Member States. ${ }^{215}$

214. The Court would actually appear to be violating Article 53 of the European Convention on Human Rights ("Safeguard for existing human rights-Nothing in this Convention shall be construed as limiting or derogating from any of the human rights and fundamental freedoms which may be ensured under the laws of any High Contracting Party or under any other agreement to which it is a Party."); Observations of Third Party Interveners at 3-4, A., B. and C., App. No. 25579/05 ("Parties to the Convention are free and encouraged to provide a higher level of protection of human rights in their own national legislation [...] The Protection of life from its beginning in Article 40.3.3 of the Irish Constitution simply constitutes a higher level of implementation of Article 2.").

215. After this article was accepted for publication the ECHR released its decision in the case on December 16, 2010. The decision instructs Ireland to legislate on when a doctor is permitted to perform an abortion because of a threat to the life of the mother. Ireland's position and legislation on abortion was found to be within the margin of appreciation doctrine. The text of the decision is available at http://www.eclj.org. 